MIECZYSŁAW WRZOSEK (Warszawa)

\title{
Z DZIEJÓW TAJNEGO NAUCZANIA I WOJSKOWEJ KONSPIRACJI NA POEUDNIOWO-ZACHODNICH OBSZARACH POEUDNIOWEGO PODLASIA W LATACH 1939-1944
}

Południowo-zachodnie obszary Południowego Podlasia stanowią znaczną część powiatu siedleckiego, który przed wybuchem drugiej wojny światowej należał do województwa lubelskiego, a w okresie okupacji niemieckiej wchodził w skład dystryktu warszawskiego w tak zwanej Generalnej Guberni. Powiat ten, oprócz miejskiego obszaru Siedlec, traktowanych na ogół jako stolica Południowego Podlasia, obejmował osiemnaście gmin, w tym dwie mające po części charakter miejski (Losice i Mordy) oraz szesnaście wiejskich, a mianowicie: Domanice, Hołubla, Huszlew, Kotuń, Królowa Niwa z siedzibą w Krzesku, Łysów, Mokobody, Niwiski, Sarnaki, Skórzec, Stok Lacki, Suchożebry, Wiśniew, Wodynie, Zbuczyn i Żeliszew. Na południowo-zachodnich krańcach Południowego Podlasia znajdowała się gmina Wodynie.

W zakres spraw poruszanych $\mathrm{w}$ niniejszym artykule wchodzą przede wszystkim te konspiracyjne wydarzenia z czasów niemieckiej okupacji, które miały miejsce na obszarze gminy Skórzec. Gmina ta, jak wiadomo, graniczy od strony wschodniej z obszarem miasta Siedlce, sąsiaduje zaś z obszarami takich gmin, jak Wiśniew od południowego wschodu, Domanice od południa, Wodynie od południowego zachodu, Żeliszew od północnego zachodu, Kotuí od strony północnej i Niwiski od północno-wschodniej. Do gminy Skórzec w okresie niemieckiej okupacji należało 18 wsi. Poczynając od południowego wschodu były to: Teodorów, Gołąbek, Wólka Kobyla, Drupia, Grala-Dąbrowizna, Żebrak, Dąbrówka Stany, Czerniejew, Nowaki, Boroszków, Cisie Zagródzie, Dąbrówka Nowa, Dąbrówka Stara, Dąbrówka Niwka, Dąbrówka Wyłazy, Dąbrówka Ług, Żelków i centralnie położona wieś Skó- 
rzec. Wsią zdecydowanie największą była Dąbrówka Stany, a do grona osad nieco mniejszych należały: Czerniejew, Nowaki, Cisie Zagródzie, Dąbrówka Wyłazy, Dąbrówka Ług, Gołąbek i sam Skórzec.

Działania bojowe na południowo-zachodnich obszarach Południowego Podlasia po stronie niemieckiej podejmował korpus „Wodrig” z 3 Armii generała Georga von Kïchlera. Był to regularny wyższy związek taktyczny, zaś na jego czele stał generał porucznik Wodrig. W skład tego korpusu wchodziły dwa związki taktyczne, a mianowicie 1 Dywizja Piechoty i 12 Dywizja Piechoty $^{1}$. Dysponował on ponadto wsparciem kombinowanej dywizji pancernej „Kempf”, której sztab wieczorem 11 września o godzinie 19.10 przebywał już w Suchożebrach oddalonych o 14 kilometrów na północ od Siedlec. Z tej właśnie wsi sztab kombinowanej dywizji meldował wówczas, że podlegające mu czołowe oddziały dotarły już na północne przedpola Siedlec ${ }^{2}$.

Duże postępy czyniła również niemiecka 1 Dywizja Piechoty z korpusu „Wodrig”. W dniu 12 września zajęła, między innymi, wieś Kotuí oraz kolonię i stację kolejową Broszków, to znaczy osiedla i obiekty usytuowane 15 kilometrów na zachód od Siedlec, które zostały jednak opanowane dopiero 13 września $^{3}$. Do Siedlec wtargnęły oddziały 12 Dywizji Piechoty ${ }^{4}$. Można zatem uznać, że okres okupacyjny w dziejach gminy Skórzec rozpoczął się także 13 września 1939 r., bo w tym właśnie dniu wojska niemieckie podążały już szosą garwolińską w kierunku południowo-zachodnim i przedostawały się na tyły wojsk polskich, które cofały się z rejonu Mińska Mazowieckiego i Kałuszyna w kierunku Łukowa.

Niemieckie formacje wojskowe dotarły w nasze strony ogólnie rzecz biorąc od strony Wschodnich Prus, ale nie sposób ustalić, czy uczyniły to wcześniej od strony Siedlec, czy od pobliskiego Kotunia. Do militarnych zma-

1 L. Herzog, Niemieckie sily zbrojne w okupowanej Polsce w latach 1939-1941, „Wojskowy Przegląd Historyczny" 1961, R. VI, nr 4 (21), s. 130.

2 J. Izdebski, Sytuacja na Podlasiu w drugiej polowie września 1939 r., w: Podlasie podczas wojny światowej, pod red. Władysława Ważniewskiego, Siedlce 1997, s. 13 i n. Ustalenia faktograficzne poczynione przez autora przytoczonego opracowania zostały oparte na mikrofilmie dokumentów niemieckiej 3 Armii, a przechowywanym w zasobach Wojskowego Biura Badari Historycznych, T-312, rolka 33.

3 Potwierdza to Stanisław Kopański, W Sztabie Naczelnego Wodza podczas kampanii wrześniowej, w: Wrzesień 1939 w relacjach $i$ wspomnieniach, wybór i opracowanie Mieczysław Cieplewicz i Eugeniusz Kozłowski, Warszawa 1989, s. 195. Przytoczoną informację generał Kopański podaje na podstawie raportu przekazanego przez pułkownika dyplomowanego Jerzego Zawiszy, który był szefem sztabu armii Lublin generała Tadeusza Piskora.

4 J. Izdebski, op. cit., s. 13. 
gań Wojska Polskiego z armią niemiecką we wrześniu 1939 r. na obszarach gminy Skórzec natomiast nie doszło. Możliwość taka istniała jednak w tym czasie, gdy dwa związki taktyczne Wojska Polskiego (1 Dywizja Piechoty Legionów generała Wincentego Kowalskiego i Mazowiecka Brygada Kawalerii pułkownika dyplomowanego Jana Karcza; była podporządkowana również generałowi Kowalskiemu) toczyły ciężkie boje z oddziałami korpusu „Wodrig" i dywizją pancerną „Kempf”). Do bojów tych doszło pod Seroczynem, Wodyniami, Oleśnicą, Wolą Wodyńską, Kamieńcem i Rudą Wolińską 5 .

Dwie ostatnie $\mathrm{z}$ wymienionych miejscowości sąsiadują $\mathrm{z}$ południowo-zachodnim pograniczem gminy Skórzec. Do wsi Dąbróki Stanów od zmierzchu 12 września do nocy z 13 na 14 września docierał więc donośny huk dział. W rejonie Rudy Wolińskiej, oddalonej zaś nie więcej niż 6 kilometrów, walczyli żołnierze 1 Pułku Piechoty Legionów pułkownika dyplomowanego Kazimierza Burczaka ${ }^{6}$. Uczestniczyli $\mathrm{w}$ zmaganiach o przełamanie trzeciego i ostatniego pierścienia sił dywizji pancernej „Kempf” i cel swój osiągnęli, pomimo dużych strat. Stwierdzenie to nie dotyczy jednak wszystkich pododdziałów grupy operacyjnej generała Kowalskiego.

Z okrążenia nie zdołał się wydostać jakiś zapóźniony oddział polskiej kawalerii. Wzmianka o tym oddziale znajduje się w meldunku niemieckiego wojskowego komendanta Siedlec majora von Auera z 18 września 1939 r. Podawał on, że zapóźniony oddział polski miał około trzystu żołnierzy i przebywał 12 kilometrów na zachód od Siedlec ${ }^{7}$. Jest to wiarygodny przekaz materiałowy, ponieważ taki oddział był okopany na leśnej polanie oddalonej o jakieś 600 metrów na zachód od wsi Dąbrówka Stany i dysponował silną artylerią. Miał 8 dział średniego kalibru, jedno działo $75 \mathrm{~mm}$ i duży zapas amunicji ${ }^{8}$.

5 Wł. Kowalski, Relacja dowódcy grupy operacyjnej „Wyszków” o dzialaniach grupy, w: Wrzesień $1939 w$ relacjach..., s. 289 i n.

6 Ibidem, passim.

7 J. Izdebski, op. cit. s. 16.

8 Jerzy Izdebski (op. cit., s. 16) powołując się na meldunek Auera wzmiankuje, że opierał się on na donosie cywilnego Niemca, obywatela polskiego. Nasuwa się tu przypuszczenie, ze tym informatorem mógł być mieszkaniec kolonii niemieckiej pod nazwą Łączka, usytuowanej w gminie Żeliszew. Wypada ponadto zaznaczyć, że miejsce postoju oddziału polskiego było oddalone od centrum Siedlec o 16 kilometrów, ale informator majora Auera mógł mieć na myśli siedleckie przemieście Rozkosz. Te uściślenia autor niniejsz.ego opracowania przedstawia tu na takiej podstawie, że pochodzi z Dąbrówki Stanów i tam właśnie mieszkał w czasie owych wydarzeń, a potem wielokrotnie przebywał w miejscu postoju oddziału polskiego i widział okopane działa, które zostały zabrane dopiero pod koniec listopada $1939 \mathrm{r}$. 
Ten polski oddział, a raczej pododdział w sile dywizjonu, był właściwie w sytuacji bez wyjścia, ponieważ zaczynało się oblężenie Warszawy, a główne działania manewrowe toczyły się już pod Lwowem. Zapóźniony pododdział polski był zaś osaczany coraz ciaśniej od południa, czyli od szosy siedlecko-garwolińskiej i przez jakiś pododdział niemiecki, który okopał się na kolonii Chabera, a więc na północno-wschodnich przedpolach Dąbrówki Stanów. W związku z tym dowódca dywizjonu polskiego zdecydował się na złożenie broni. Uczynił to w nocy, zapewne z 18 na 19 września. Rozbrajanie żołnierzy polskich przez Niemców odbywało się, przy świetle reflektorów na wiejskiej ulicy Dąbrówki Stanów ${ }^{9}$.

Ten wstępny okres niemieckiej okupacji południowo-zachodnich obszarów Południowego Podlasia nie trwał jednak długo. W dniu 21 września niemieckie Naczelne Dowództwo Wojsk Lįdowych (Oberkommando des Heeres) powiadomiło podległe armie, że mają wycofać swoje formacje wojskowe na zachód i wydało $w$ tej sprawie odpowiedni rozkaz ${ }^{10}$. Wojska niemieckie miały ustąpić na linię demarkacyjną, która była uzgodniona przez Niemcy i sowiecką Rosję w układzie Ribbentrop - Mołotow z 23 sierpnia 1939 r., czyli na linię Pisy - Narwi - Bugu i Sanu. Niemieckie dywizje miały ustąpić na linię Pisy do 28 września, na linię Narwi w rejonie Ostrołęki do 29 września wieczorem, na linię Wisły w rejonie Dęblina do 3 października wieczorem, a zakończenie całej operacji zostało przewidziane 4 października wieczorem ${ }^{11}$. W pierwszym rzucie było planowane wycofanie jednostek tyłowych, a oddziały liniowe miały blokować Pragę do tego czasu, gdy na wschodnie przedpola Warszawy dotrą formacje Armii Czerwonej. Z wzajemnych uzgodnieí wynikało, że podczas niemieckich ruchów odwrotowych, między oddziałami Wehrmachtu a formacjami Armii Czerwonej będzie zachowana luka licząca 25 kilometrów. Nad przebiegiem operacji mieli czuwać oficerowie łącznikowi, a do ich zadaí należało usuwanie wszelkich niejasności ${ }^{12}$.

W dniu 22 września 1939 r. formacje Armii Czerwonej przekroczyły linię Bugu i przesuwały się dość wolno w kierunku Wisły. Na obszarach Podla-

9 Osobiste wspomnienia autora niniejszego artykułu, który był naocznym świadkiem tego bardzo przykrego wydarzenia. Te obserwacje były czynione z ukrycia wspólnie z Ojcem, Czesławem Wrzoskiem. Żołnierze polscy byli poddawani skrupulatnej rewizji i widziałem dokładnic, że musieli oddawać pasy główne, a potem wspinali się do pilnowanych przez Niemców ciężarowych samochodów odjeżdżających w kierunku Skórca, a następnie do obozów jenieckich.

10 J. Izdebski, op. cit., s. 16.

11 Ibidem, passim.

12 Ibidem, s. 17. 
sia pojawiły się wojska Frontu Białoruskiego komandarma Michaiła Prokofiewicza-Kowalowa. Wojska te działały według rozkazu $\mathrm{nr} 05$, jaki wydał 22 września 1939 r. W strefie północnej, sięgającej od strony południowej po linię Prużany - Kamieniec Litewski - Siedlce - Garwolin, miały operować związki taktyczne 10 Armii komkora Iwana Grigoriewicza Zachrkina. Do działań w strefie wyznaczonej na południe od tych obszarów, aż po linię Dąbrowica - Kock - Dęblin, została skierowana 4 Armia komdywa Wasilija Iwanowicza Czujkowa ${ }^{13}$. Z rozkazu 011, wydanego 27 września przez dowódcę 4 Armii wynika, że jej dywizje po upływie dwóch dni miały dotrzeć po linię: Sokołów Podlaski - Siedlce - Łuków ${ }^{14}$.

W rozkazie tym chodziło wszakże również o zajęcie obszarów podmiejskich, usytuowanych na zachód od wymienionych miast. Wynika to z ustaleí, do jakich doszło 28 września podczas negocjacji oficerów łącznikowych, w których stronę niemiecką reprezentowali podpułkownik doktor Spalsky i kapitan Herre przy współudziale dowódcy batalionu rozpoznawczego podpułkownika von Watzendorfa. Uzgodniono tam wówczas, że wojska niemieckie zakończą ewakuację Siedlec 29 września o godzinie 9 rano i wycofają się najpierw na zachód od linii Ostrołęka - Ostrów Mazowiecka - Węgrów wieś Polaki (usytuowana 2 kilometry na zachód od Kotunia, czyli 16 kiloInetrów na zachód od Siedlec). Tereny opuszczane tam przez wojska niemieckie miały być zajmowane przez oddziały 10 Armii wojsk radzieckiego Frontu Białoruskiego i 4 października miały one dotrzeć po linię Ostrołęka - Wyszków - Mińsk Mazowiecki ${ }^{15}$. Odpowiednie postępy miały czynić również formacje 4 Armii, ale nie udało się ustalić do jakiej linii miały dotrzeć w tym samym czasie.

Wiadomo natomiast, że postępy radzieckiej 4 Armii ku Wiśle zostały wstrzymane. Ich przerwanie spowodowal kolejny rozkaz komdywa Czujkowa $\mathrm{nr} 012$, wydany 29 września o godzinie $18.00^{16}$. Nie wykluczone, że ten rozkaz został sporządzony na podstawie nagłych sygnałów, jakie dotyczyły terytorialnych ustaleń zawartych w nowym układzie Ribbentrop - Mołotow, zawartym w nocy z 27 na 28 września 1939 r. W dwa dni później, czyli 30 września o godzinie 11.30, dowódca wojsk Frontu Białoruskiego wystawił

13 Ibidem, s. 17 i n.

14 Rozkaz komdywa Czujkowa nr 011 z 27 września 1939 r., w: Agresja sowiecka na Polskę w świetle dokumentów, 17 września 1939 r., „Bellona” 1995, t. 3, s. 296.

15 J. Izdebski, op. cit., s. 20.

16 Ibidem, s. 19. 
natomiast rozkaz $\mathrm{nr} 015$, który zawierał informacje o przesunięciu niemiecko-sowieckiego rozgraniczenia na linię Bugu. Wycofywanie oddziałów Armii Czerwonej poza tę linię demarkacyjną miało się zacząć 5 października w godzinach porannych ${ }^{17}$. Oznaczało to, że nastąpi powrót wojsk niemieckich na podlaskie tereny opuszczane przez oddziały Armii Czerwonej. Z rozkazu wystawionego 30 września przez dowództwo niemieckiej Grupy Armii „Pólnoc" wynikało zaś, że ten powrót powinien się rozpocząć niby nie wcześniej, niż 2 października.

Taka zapowiedź sprawiła, że dowódcy niektórych niemieckich związków taktycznych podjęli już 1 października wstępne przygotowania do działań mających na celu ponowne zajęcie terenów opuszczanych przez oddziały Armii Czerwonej. W ten właśnie sposób postąpił dowódca niemieckiej 13 Dywizji Piechoty Zmotoryzowanej i wysłał oficera łącznikowego do radzieckiego komendanta $\mathrm{w}$ Lukowie $\mathrm{w}$ celu nawiązania $\mathrm{z}$ nim kontaktu. Tym niemieckim oficerem był major Lomke ${ }^{18}$. Do Łukowa podążał $w$ towarzystwie thumacza Sieberta jednym $\mathrm{z}$ trzech skierowanych tam samochodów pancernych, rozbitych na północ od Kocka przez kaprala Modrzejewskiego z 2 Pułku Ułanów Grodzieńskich. Wiózł pismo zawierające prośbę o pomoc w działaniach skierowanych przeciw Samodzielnej Grupie Operac:yjnej „Polesie” generała Franciszka Kleeberga ${ }^{19}$.

Do przejęcia obszarów Południowego Podlasia zostały skierowane trzy związki taktyczne XIV Korpusu z niemieckiej 10 Armii, a mianowicie 29 Dywizja Piechoty Zmotoryzowanej, 26 Dywizja Piechoty i 213 Dywizja Piechoty. Wymienione dywizje operowały na podstawie porozumienia uzgodnionego 5 października w Mińsku Mazowieckim z przedstawicielami dowódcy radzieckiej 4 Armii komdywa Czujkowa. W tym spotkaniu stronę niemiecką reprezentowali pułkownik Weiss i kapitan Weber, a sowiecką major Maniewicz i starszy lejtinant Malew. Uzgodniono tam, że oddziały Armii

17 Ibidem, s. 20.

18 T. Grzeszkowski, Dzialania Samodzielnej Grupy Operacyjnej „Polesie” (Z relacji uczestnika walk), w: Wrzesien 1939, w relacjach..., s. 792 . W przekazach materiałowych dotyczących tego niemieckiego oficera utrzymuje się pozorna rozbieżność. Polega na tym, że pułkownik Tadeusz Grzeszkowski wymienił tylko jego stopień wojskowy (major) i szlachecki tytuł: „Freiherr” (odpowiednikiem tego określenia w języku polskim jest zaś słowo: „baron”. Redaktorzy wspomnień wrześniowych (Mieczysław Cieplewicz i Eugeniusz Kozłowski) słowo niemieckie. Freiherr potraktowali natomiast jako nazwisko, ale zaznaczyli, że w innych źródłach występuje on jako kapitan dyplomowany Lomke, a jeszcze inny autor (Jerzy Izdebski, op. cit., s. 20) zaznaczył iż był to kapitan dyplomowany Lunke. W istocie był to zwyczajny baron von und zu Lomke, vel Lunke.

19 T. Grzeszkowski, op. cit., s. 792. 
Czerwonej 5 października ustąpią na linię Sokołów Podlaski - Siedlce - Łuków. W następnych dniach miały się one wycofywać na kolejne, ustalone wówczas linie, a 11 października było przewidziane ich całkowite odejście za Bug ${ }^{20}$.

Po ustąpieniu oddziałów Armii Czerwonej rozpoczął się nowy, tym razem znacznie dłuższy okres okupacji niemieckiej na obszarach Południowego Podlasia. Przez trzy tygodnie utrzymywal się tu system okupacyjnej administracji wojskowej, zapowiedzianej odezwą dowódcy niemieckich wojsk lądowych, to znaczy generała Walthera von Brauchitscha. Zawierała ona zarządzenia, które obowiązywały od 1 września 1939 r. Wprowadzana administracja miała charakter władzy stosowanej na terytoriach traktowanych jako obszar okupacji wojennej. Atrybuty takiej władzy wynikały z przepisów zamieszczonych w III Dziale IV Konwencji Haskiej z 18 października 1907 r., a ujętych pod tytułem: „O władzy wojennej na terytorium państwa nieprzy jacielskiego" Analiza odezwy generała von Brauchitscha uzewnętrznia nawet wyraźną intencję zachowania pozorów, że system administracyjny, narzucany opanowanym ziemiom polskim, to właśnie ustrój okupacji wojennej ${ }^{21}$.

Oficjalną decyzję w sprawach dotyczących obszaru położonego na południe i wschód od powiększonego terytorium państwa niemieckiego komunikowal nowy dekret Wodza i Kanclerza Rzeszy o Administracji Okupowanych Terytoriów Polskich z 12 października 1939 r. Określał on terytorialny zasięg obszaru, którego dotyczył i ustalal przyznane mu formy ustrojowo-prawne. Nie zawierał natomiast nazwy powoływanego tworu administracyjnego, ale stwierdzał, że zwierzchnikiem władz będzie minister Rzeszy doktor Hans Frank. Dygnitarz ten mial występować jako generalny gubernator. Stąd nazwa powołanej jednostki administracyjnej: Generalna Gubernia (Generalgouvernement) ${ }^{22}$.

Wprowadzenie dekretu nie nastąpiło $w$ trybie natychmiastowym. W pięć dni później, to znaczy 17 października w sprawach dotyczących tego obszaru odbyła się w Berlinie bardzo ważna konferencja. Uczestnikami tego spotkania, oprócz Hitlera, byli: jego zastępca Rudolf Hess, szef kancelarii

20 J. Izdebski, op. cit., s. 22.

21 M. Wrzosek, Zaczq̨tki niemieckiego systemu okupacyjnego na terytoriach polskich opanowanych przez wojska niemieckie jesieniq 1939 roku, „Studia Podlaskie” 1996, t. VI, s. 49.

22 Ibidem, s. 64. 
NSDAP Martin Bormann, dowódca SS Heinrich Himmler, szef Naczelnego Dowództwa Wehrmachtu (Oberste Kommando der Wehrmacht - OKW) generał Wilhelm Keitel, minister spraw wewnętrznych Wilhelm Frick i doktor Hans Frank. Ustalono wówczas, że obszar administracyjny określany już faktycznie jako Generalna Gubernia, będzie na razie „tymczasowym rezerwatem" dla ludności tam już zamieszkałej oraz dla przesiedleńców z ziem wcielonych do Rzeszy ${ }^{23}$. Decyzja o odwołaniu wojskowej władzy okupacyjnej obszarów położonych na południe i wschód od nowych granic: Rzeszy, zapadła natomiast 19 października, a istnienie tworu administracyjnego, nie traktowanego już jako teren okupowany, czyli zajęty na okres przejściowy, lec:z jako obszar „zdobyty”, a raczej podbity i zagarnięty bezpowrotnie. Postanowienie oparte na takich zamysłach, które nie zostały jednak formalnie uzewnętrznione, podjął Hitler nie licząc się ze stanowiskiem szefa OKW 24 . Istnienie tworu administracyjnego, określonego jako Generalna Gubernia, datowało się natomiast od 26 października $1939 \mathrm{r}$.

Skoro terytorium Generalnej Guberni miało być traktowane jako obszar „zdobyty”, to nasuwa się istotna kwestia dotycząca sił wojskowych i policyjnych przeznaczonych do zabezpieczenia niemieckiego panowania na tym właśnie terytorium. Na podstawie dostępnych przekazów materiałowych nie sposób jednak dojść w tych sprawach do ustaleń dokładnych. W odniesieniu do sił wojskowych nie pozwala na to również taka okoliczność, że ich liczebność miała charakter płynny i była uzależniona od aktualnej sytuacji wojennej. Główna część tych związków taktycznych, które uczestniczyły w militarnej napaści na Polskę, była odwołana na front zachodni. Systematyczny przewóz kierowanych tain wojsk trwał od 18 września do 20 października 1939 r., a jego natężony charakter zaznaczał się od 29 września ${ }^{25}$.

23 M. Broszat, Polityka narodowego socjalizmu w sprawie Polski. 1939-1945 (ttumaczenie), Warszawa - Poznaí 1966, s. 38.

24 Fragment wypowiedzi Hansa Franka na posiedzeniu szefów Rządu Generalnej Guberni w dniu 19 stycznia 1940 r.: „15 września otrzymałem zadanie, aby objąć zarząd zdobytych obszarów na wschodzie, ze specjalnym rozkazem bezwzględnego grabienia tego obszaru jako terenu wojennego i zdobytego, publ. St. Piotrowski, Dziennik Hansa Franka, Warszawa 1957, s. 402. Por. także T. Brustin-Berenstein, O niektórych zagadnieniach gospodarczych w tzw. Generalnej Guberni w świetle „Dziennika Frunka”, „Biuletyn Żydowskiego Instytutu Historycznego" 1954, nr 9-10, s. 238.

25 L. Herzog, op. cit., s. 121. Autor innego opracowania (K. Radziworiczyk, Wojenny zarz̨d okupacyjny Wehrmachtu, w: Polski ruch oporu 1939-1945, red. nauk. Bogdan Kobuszewski, Piotr Matusak, Tadeusz Rawski, Warszawa 1988, s. 30) podaje, że intensyfikacja przewozu wojsk niemieckich na front zachodni zaznaczała się w dniach od 29 września do 5 października. Ta rozbieżność nie ma jednak dla nas istotnego znaczenia. 
Po ewakuacji odwołanych formacji na polskich terenach objętych cywilną administracją okupacyjną pozostało jednak jeszcze 30 dywizji wojska niemieckiego, co wynika, między innymi z poważnego opracowania niemieckiego $^{26}$. Z szacunków opartych na podstawie takiej informacji wynika, że na polskich terytoriach znajdujących się pod niemieckim panowaniem, 25 października 1939 r. przebywało jeszcze około 800 tysięcy wojska'27. Wiosną 1940 r. nastąpiła dalsza, dość znaczna redukcja niemieckich sił wojskowych na ziemiach polskich. Wiadomo mianowicie, że do 4 czerwca tegoż roku na front zachodni odwołano jeszcze dziesięć dywizji piechoty, $\mathrm{z}$ tego aż dziewięć z samej Generalnej Guberni, a przybyły tu tylko dwie zapasowe brygady piechoty. W wyniku takich przemieszczeń od pierwszej dekady czerwca na terytorium Generalnej Guberni przebywało już tylko dziewięć dywizji piechoty, a na ziemiach wcielonych do Rzeszy jeszcze dwanaście dywizji. Ogólny stan osobowy tych formacji oraz różnych pomniejszych, ale licznych jednostek wojskowych, jest określany w odniesieniu do tego okresu na około 500 tysięcy ${ }^{28}$. Oznacza to, że na terenie Generalnej Guberni mogło być wówczas w ich szeregach tylko 200, a może 210 tysięcy regularnych wojsk.

Taki stan utrzymywał się do wiosny 1941 r., gdy na obszarach Generalnej Guberni rozpoczęła się ogromna koncentracja wojsk niemieckich w ranıach przygotowań do uderzenia na Związek Radziecki. W okresie następnym, gdy linia frontu wschodniego przesunęła się w głąb obszarów dotychczasowego sprzymierzeńca, liczba wojsk niemieckich na terytorium Generalnej Guberni znowu gwałtownie zmalała. Jesienią 1941 r. zaznaczył się tu jednak kolejny wzrost liczebności niemieckich sił wojskowych i na terytoriach zniewolonej Rzeczypospolitej przebywały formacje liczące ogólem milion żołnierzy. Decydowały o tym stany osobowe formacji odwodowych wojsk znajdujących się na linii frontu oraz te jednostki wojskowe, które były wycofywane $\mathrm{z}$ frontu na wypoczynek. Taka sytuacja utrzyınywała się do lata 1944 r. Nie sposób wprawdzie dokładnie ustalić, jaka część tych sił przebywała na terytoriuın Generalnej Guberni, ale ınożna przypuszczać, że nie mniej niż 300, a może nawet 350 tysięcy osób.

W tym okresie, gdy już nastąpiło osłabienie procesu pierwszej redukcji wojsk niemieckich na ziemiach polskich, a tym samym i na terytorium Generalnej Guberni, kształtowały się tu struktury cywilnego systemu oku-

K. Radziwoniczyk, op. cit., s. 40. 
pacyjnego. Powierzchnia tego administracyjnego tworu miała 93600 kilometrów kwadratowych i mieszkało tu początkowo 11863000 osób, w tym 9792000 Polaków, 1457000 Żydów, 526000 Ukraińców i Białorusinów, 65000 Niemców oraz 23000 osób innych narodowości ${ }^{29}$. Na czele Generalnej Guberni, jak już wiadomo, stał doktor Hans Frank, a jego zastępcą do maja 1940 r. był Arthur Seyss-Inquart, potem zaś Joseph Bühler, który był jednocześnie kierownikiem centralnego organu administracyjnego określanego oficjalnie jako Rząd Generalnej Guberni. Organ określany rządem miał Sekretariat Stanu oraz trzynaście tak zwanych wydziałów głównych dla spraw wewnętrznych, finansów, sprawiedliwości, gospodarki, wyżywienia i rolnictwa, leśnictwa, pracy, propagandy, nauki, wychowania i wykształcenia ludowego, budownictwa, kolei, a także poczty ${ }^{30}$.

Pod względem administracyjnym Generalna Gubernia dzieliła się na cztery obszary administrac:yjne. Były to dystrykty: Kraków, Lublin, Radom i Warszawa; władzę w poszczególnych dystryktach sprawowali zaś gubernatorowie. Niższą jednostką administracyjną był powiat (Kreis). Występowały jednak zarówno powiaty grodzkie, powołane dla miast dużych i niektórych większych, a także powiaty ziemskie. W każdym dystrykcie było dziesięć powiatów i dzieliły się one na gminy obejmujące mniejsze miasta oraz wsie. $\mathrm{Na}$ czele powiatu stał starosta (Kreishauptmann). Wszystkie kierownicze stanowiska w strukturze administracji cywilnej obszaru Generalnej Guberni zajmowali Niemcy. Funkcjonowali w niej jednak także Polacy, ale byli zatrudniani tylko jako personel pomocniczy i całkowicie uzależniony od niemieckich władz okupacyjnych ${ }^{31}$.

Władza oraz działalność okupacyjnej cywilnej administracji, zabezpieczona w Generalnej Guberni już przez samo to, że na jej terytorium istniały duże garnizony wojskowe, opierała się na szeroko rozbudowanym aparacie policji oraz na silnych formacjach tak zwanych Sztafet Ochronnych (Schutz Staffeln; w skrócie SS) partii nazistowskiej NSDAP). Policja niemiecka, podlegająca od 17 czerwca 1936 r. Heinrichowi Himmlerowi, dzieliła się na dwa zasadnicze piony, to znaczy na policję porządkową (Ordnungspolizei - Orpo) i na policję bezpieczeństwa (Sicherheitspolizei - Sipo). W skład policji porządkowej wchodziły z kolei: policja ochronna (Schutzpolizei - Schupo)

29 Cz. Madajczyk, Polityka III Rzeszy w okupowanej Polsce, t. I, Warszawa 1970, s. 66 .

30 Ibidem, s. 107-109.

31 R. Herzog, Grundzüge der deutschen Besetzungsverwaltung in den ost - und südosteuropäischen Ländern während des zweiten Weltkrieges, Tübingen 1955, s. 34-36. 
rozlokowana w miastach, żandarmeria (Gendarmerie) rozlokowana posterunkami w miasteczkach i gminach wiejskich, policja wodna (Wasserpolizei), policja ogniowa (Feuerschutzpolizei), policja pomocnicza (Hilfspolizei) oraz zwarte bataliony policji skoszarowanej. Do policji bezpieczeístwa natomiast należały: tajna policja państwowa (Geheime Staatspolizei - Gestapo), policja kryminalna (Kriminalpolizei - Kripo) ${ }^{32}$.

Zwierzchnikiem policji niemieckiej, jak to zostało już zaznaczone, był Himmler, który oficjalnie podlegał niby ministrowi sprawa wewnętrznych, ale faktycznie zajmowal stanowisko równorzędne i bral udzial $\mathrm{w}$ posiedzeniach gabinetu Rzeszy, był bowiem ogólnopaństwowym dowódcą, czyli reichsführerem SS. Podlegały mu dwa związane ściśle z policją tak zwane główne urzędy, a mianowicie: Główny Urząd Policji Porządkowej (Hauptamt der Ordnungspolizei) i Główny Urząd Policji Bezpieczeństwa (Hauptamt der Sicherheitspolizei), od 29 września połączony z Głównym Urzędem Służby Bezpieczeństwa, którym dotychczas dysponowało dowództwo SS w Rzeszy (Reichsführung SS). Tej organizacyjnej fuzji towarzyszyło przemianowanie połączonych organów i występowały już nadal jako Główny Urząd Bezpie(zeństwa Rzeszy (Reichsicherheitshauptamt - RSHA) ${ }^{33}$.

Zwierzchnictwu wymienionych organów policyjnych Rzeszy podlegały również siły policyjne Generalnej Guberni. Dowódcą zainstalowanych tu sił policji bezpieczeństwa został SS-brigadeführer Bruno Streckenbach. Terenowymi organami tego pionu policyjnego były zaś ekspozytury Gestapo i SD. Zostały one ulokowane jednak nie tylko w stolicach dystryktów, ale także w większych miastach powiatowych, a komisariaty Kripo istniały we wszystkich miastach powiatowych. Na terenie wschodnich i południowych powiatów Generalnej Guberni istniały ponadto komisariaty i posterunki policji granicznej. W kwietniu 1940 r. jedostki tego pionu sił policyjnych miały łącznie prawie 3 tysiące funkcjonariuszy, w tym Gestapo i policja graniczna ponad 1500, SD około 200, a Kripo $1250^{34}$.

Na czele policji porządkowej w Generalnej Guberni stał natomiast generał Herbert Becker. Podlegały mu zaś siły policji ochronnej i żandarmerii.

32 M. Wrzosek, Niemieckie sily policyjne na Górnym Ślq̨sku w rejencji katowickiej w' okresie od września do grudnia 1939 r., „Biuletyn Głównej Komisji Badania Zbrodni Hitlerowskich w Polsce" 1967, nr XVII, s. 112; por. także: E. Cranshaw, Gestapo narzędzie tyranii, Warszawa 1959, s. 64 i n.; Z. Janowicz, Ustrój policji niemieckiej na ziemiach polskich wcielonych do Rzeszy niemieckiej, 1939-1941, Poznań 1951, s. 357; F. Ryszka, Paristwo stanu wyjatkowego, Wrocław 1964, s. 279.

33 M. Wrzosek, Niemieckie sily policyjne..., s. 112.

34 K. Radziwończyk, op. cit., s. 37. 
Policja ochronna była ulokowana $w$ stolicach dystryktów i w takich miastach wydzielonych, które były jednocześnie siedzibaini władz powiatowych. Pozostałe miasta powiatów otrzymały natomiast po plutonie żandarmerii, a trzy plutony tego rodzaju sił policyjnych stanowiły łącznie kompanię, określaną jednak jako „oddział główny” (Hauptmanschaft) ${ }^{35}$. Komendant Orpo każdego dystryktu dysponował ponadto pułkiem złożonym z pięciu batalionów skoszarowanej policji. W połowie $1940 \mathrm{r}$. żandarmeria Generalnej Guberni miała 2285 funkcjonariuszy, a ponadto w trzynastu batalionach skoszarowanej policji porządkowej pełniło służbę ponad 6500 funkcjonariuszy $^{36}$. Dość znaczne zwiększenie niemieckich sił wojskowych i policyjnych na terytorium Generalnej Guberni zaznaczyło się potem zwłaszcza w drugiej połowie 1943 r., gdy nastąpił wzrost ruchu partyzanckiego, polskiego i radzieckiego ${ }^{37}$.

Jako uzupełnienie wymienionych sił policyjnych w Generalnej Guberni występowała ponadto polska, tak zwana policja granatowa. Była powołana 30 października 1939 r. na podstawie zarządzenia wydanego przez wyższego dowódcę SS i Policji Friedricha Wilhelma Krügera. Wezwał on do służby w tej formacji policyjnej tych wszystkich, którzy w dniu 1 września 1939 r. pełnili obowiązki jako czynni funkcjonariusze byłej polskiej Policji Państwowej. Zostali oni zobowiązani do niezwłocznego zgłoszenia się w najbliższym urzędzie policji niemieckiej lub starostwie w celu podjęcia dalszej służby. Termin stawienia się upływał 10 listopada 1939 r. ${ }^{38}$

Takiemu oto systemowi była również podporządkowana południowo-zachodnia część Południowego Podlasia, czyli konkretnie obszar powiatu siedleckiego. Główna część sił wojskowych, skierowanych do tego regionu, została ulokowana w Siedlcach. W tym mieście osiadły też lokalne orga-

35 Ibiden, passim. „Hauptmannschaft”, to określenie występujące w języku niemieckim jako wyraz złożony z dwóch słów, przymiotnika haupt (główny) i rzeczownika oddział albo drużyna (Mannschaft), łącznie „Haupt - Mannschaft”. Ten wyraz jest jednak zazwyczaj źle tłumaczony na język polski. Policyjny „Hauptmannschaft” jest faktycznie odpowiednikiem wojskowej kompanii. W polskich opracowaniach występuje jednak jako rzekomy „kapitanat”, czyli określenie stosowne dla portów. Por. m.in.: K. Radziworiczyk, op. cit., s. 37. Jako „kapitanat” jest podawany także przez innych historyków, nawet autorów poważnych opracowań dotyczących systemu niemieckiej okupacji w Generalnej Guberni i na obszarach wcielonych do Rzeszy.

36 K. Radziwończyk, op. cit., s. 37.

37 P. Matusak, K. Radziwoíczyk, Okupant wobec narastania michu oporı. Walka z polskq oświatq, kulturq̨ i Kościolem. Generalny plan wschodni, w: Polski ruch oporu..., s. $163-167$.

38 R. Litwiíski, Policja Paristwowa w województwie lubelskim w latach 1919-1939, s. 287. 
ny władz administracyjnych i policyjnych. Kluczową rolę w administracji odgrywał tu starosta Friedrich Gercke, zastąpiony później przez Franza Seemanna oraz faktyczny prezydent miasta Albert Fabisch, tytułowany „komisarzem". Duże znaczenie mieli ponadto: kierownik Urzędu Pracy (Arbeitsamtu) Klene, szef lokalnej placówki Sipo i SD Julius Dube, komendant Kripo Ludwik Kraft, a także dwaj oficerowie Orpo, a mianowicie Bujnis i Friecke, którzy mieli do swej dyspozycji oddział główny żandarmerii (Hauptmannschaft) i oddział główny Schupo (Hauptmannschaft) ${ }^{39}$. W dostępnych opracowaniach istnieją wzmianki o siłach Schupo oraz żandarmerii na obszarze powiatu siedleckiego. Ze stwierdzenia dotyczącego Schupo wynika niby, ze cały powiatowy pododdzial Schupo był zakwaterowany w Broszkowie (Kotuniu), ale w dyspozycji jednego oficera znajdowało się tam zaledwie 48 funkcjonariuszy. Powiatowe siły Schupo prezentują się zatem chyba zbyt skromnie.

Nasuwa się mianowicie przypuszczenie, że w tej informacji chodzi tylko o jeden $\mathrm{z}$ trzech plutonów policji ochronnej rozlokowanej na obszarze powiatu ${ }^{40}$. Podobna wątpliwość nasuwa się również w odniesieniu do stanu osobowego żandarmerii powiatu siedleckiego, skoro 26 maja 1943 r. miała rzekomo tylko 4 oficerów oraz 41 funkcjonariuszy. Nie było też tak, że posterunki tej powiatowej żandarmerii zostały rozlokowane jedynie w Siedlcach i Łosicach ${ }^{41}$. Wiadomo natomiast, że powiat siedlecki miał aż 16 gmin wiejskich, a w każdej $\mathrm{z}$ nich musiał istnieć posterunek żandarmerii, ponieważ żandarmeria występowała w niemieckim systemie jako służba policyjna gmin wiejskich ${ }^{42}$. W powiecie siedleckim

39 H. Piskunowicz, ZWZ-AK w powiecie siedleckim 1939-1945, Siedlce 1992, s. 2.

40 Ibidem, passim. Stwierdzenie dotyczące pobytu jednego plutonu Schupo w powiecie siedleckim budzi wątpliwości. $\mathrm{Na}$ ich rozwianie nie pozwala wszakże brak odpowiednich przekazów źródłowych. Możliwość uzyskania pośrednich wyjaśnień zapewnia jednak zastosowanie porównawczej metody dociekań, okazuje się bowiem, że na obszarach rejencji katowickiej występowały wprawdzie takie pododdziały żandarmerii, które miały zaledwie 2 podoficerów i 32 funkcjonariuszy, ale kontrolowały one obszar powiatu za pośrednictwem tylko czterech posterunków. Tak było na przykład w powiecie tarnogórskim (posterunki: Tarnowskie Góry, Miasteczko, Piaseczno i Nakło). Odział rybnicki kontrolował zaś tam teren za pośrednictwem tylko trzech posterunków, a miał 4 podoficerów i aż 79 żandarmów; por. ustalenia: M. Wrzosek, Niemieckie sily policyjne na Górnym Śląsku..., s. 117.

41 Ibidem, passim. W opracowaniu zawierającym informację o siłach żandarmerii powiatu siedleckiego są wymienione tylko dwa posterunki (jeden w Siedlcach, drugi w Losicach).

42 J. Sehn, Organizacja policji niemieckiej w Rzeszy i Generalnej Guberni, „Biuletyn Głównej Komisji Badania Zbrodni Niemieckich w Polsce”, t. III, s. 177; por. także: Z. Janowicz, op. cit., s. 527. 
było natomiast rzeczywiście 157 funkcjonariuszy tak zwanej policji granatowej ${ }^{43}$.

Dalsza część artykułu będzie dotyczyła Gminy Skórzec. Ta gmina pod względem obszaru i stanu zaludnienia była zaliczana do grupy terenowych jednostek administracyjnych o wielkości średniej. W latach poprzedzających bezpośrednio wybuch drugiej wojny światowej była zamieszkiwana niemal wyłącznie przez Polaków, ponieważ na jej obszarze mieszkało zaledwie kilka rodzin ludności żydowskiej ${ }^{44}$. Była też jedna czteroosobowa rodzina ukraińska, Bazylego i Olgi Mielników, nauczycieli gminnej szkoły w Skórcu. Podczas okupacji prawie wszyscy Żydzi zostali zamordowani, częściowo jako mieszkańcy siedleckiego getta, a częściowo na polu wsi Skórzec, przy zakręcie polnej drogi do wsi Nowaki; zostali tam zastrzeleni przez funkcjonariuszy gminnego posterunku niemieckiej żandarmerii. Byli tam też pochowani około 10 osób schwytanych w tym czasie. Te morderstwa zostały dokonane w okresie przejściowym, gdy Żydzi mieli już obowiązek zamieszkania na terenie wyodrębnionej dzielnicy Siedlec, czyli w getcie, a ci, którzy jeszcze tego nie uczynili, byli przez niemieckich funkcjonariuszy policyjnych nieustannie tropieni. Ci funkcjonariusze grasowali po całej okolicy. Schwytanych nie odstawiali do getta, ale ich niezwłocznie mordowali właśnie przy drodze do Nowak ${ }^{45}$.

Uratowani zostali natomiast dwaj Żydzi, mieszkańcy wsi Dąbrówki Stanów. Jednym był Szulim Silberstein, który w getcie nie mieszkal. Ukrywał się natomiast wraz z rodziną w leśnym bunkrze koło wsi Gołąbek. Pewnego dnia na przełomie lat 1942 i 1943, gdy wraz z czteroletnią córką przebywał poza kryjówką, żandarmi zamordowali pozostałych członków jego rodziny. Potem ukrywał go Stanisław Dąbrowski w Dąbrówce Stanach. Po wojnie wyemigrował do Izraela ${ }^{46}$. Drugim uratowanym kilkunastoletnim Żydem był natomiast syn szklarza Lejby. Został ochrzczony i uzyskał aryjskie dokumenty na nazwisko Chrościcki, ale ukrywał się nadal. Był przechowywany przez Aleksandra Potyrę we wsi Dąbrówka Stany. Po wojnie został urzędnikiem gminnym w Eosicach ${ }^{47}$.

43 H. Piskunowicz, op. cit., s. 3.

44 Trzy rodziny żydowskie (młynarza, szklarza i szewca) mieszkały we wsi Dąbrówka Stany, rodzina innego szewca mieszkała w gminnej wsi Skórcu, a jakieś dwie rodziny żydowskie żyły we wsi Gołąbku.

45 Osobiste wspomnienia autora niniejszego artykułu.

46 Relacja Stanisława Dąbrowskiego (wuj autora) i osobiste wspomnienia autora.

47 Wspomnienia autora. 
Do jeszcze większego ubytku liczby mieszkańców gminy Skórzec podczas okupac.ji przyczynił się wywóz osób powoływanych na przyınusowe roboty w Rzeszy. Zaznaczyły się ponadto w tej gminie spore zmiany demograficzne. Były spowodowane zarówno przybyciem licznych osób wysiedlanych przez władze niemieckie $\mathrm{z}$ obszarów wcielonych do Rzeszy jesienią 1939 r., jak też napływem takich, którzy czuli się zagrożeni w dotychczasowych miejscach pobytu, a na wsi szukali schronienia i spokojniejszej egzystenc.ji, albo pojawiali się w poszukiwaniu możliwości łatwiejszego niż w inieście przetrwania ówczesnych okrutnych czasów. Pełnego obrazu zmian demograficznych całej gininy nie sposób ująć, ale można ocenić ich rozmiary na podstawie tego, co działo się w osadzie gminnej i w Dąbrówce Stanach, największej wsi gminy Skórzec.

Wiadomo mianowicie, że latem $1941 \mathrm{r}$., po wyjeździe do Lwowa rodziny Mielników, w siedmioklasowej szkole powszechnej, która funkcjonowała w Skórcu, zaczęła nauczanie Feliksa Wąsikowa. Była żoną oficera Wojska Polskiego, który zginął jesienią 1939 r., a przed wybuchem wojny mieszkała w Ostrowiu Wielkopolskim i była tain nauczycielem gimnazjalnym. Jako nowy nauczyciel pojawił się również w tej szkole Jan Lipiński, wysiedlony (albo uchodźca) z rejonu Kutna. W Skórcu został też zatrudniony lekarz weterynarii podporucznik Ludwik Ossowski i zamieszkał wraz bratem Henrykiem Ossowskim. Do grona bardziej znanych osób należało ponadto małżeístwo Józefa i Józefy Tomaszewskich. Byli oboje osobami inteligenckiego pochodzenia i znali świetnie język niemiecki.

We wsi Dąbrówce Stanach już jesienią 1940 r. zaczęli się pojawiać nowi mieszkańcy. Najpierw zatrzymali się w naszej wsi dwaj uchodźcy w wieku około 20 lat. Byli to Witold Lorentowicz i Antoni Wrzosek. Przybyli już późną jesienią 1939 r. z Czyżewicz usytuowanych na północ od Brześcia Litewskiego, a trzy kilometry na wschód od Bugu. Obaj szukali schronienia przed wywózką w głąb bezkresnych obszarów Związku Radzieckiego. Antoni był synem Stanisława Wrzoska, czyli brata mojego dziadka Teofila. Zimą 1940 r. Stanisław Wrzosek został wywieziony wraz z żoną Anastazją oraz sześciorgiem dzieci, młodszych niż Antoni, gdzieś na Ural i ślad po nich zaginą ${ }^{48}$. Jesienią 1939 r. pojawił się też właściciel dużego gospodarstwa rolnego spod Łomży i przebywając w Dąbrówce Stanach do lata 1941 r. prowadził

48 Antoni Wrzosek, w 1941 r. zamieszkał u starszej, już zamężnej siostry w rejonie Międzyrzeca Podlaskiego, następnie służył w 2 Armii ludowego Wojska Polskiego i uczestniczył w walkach o Kołobrzeg, a po odejściu do cywila przebywał na odzyskanych Ziemiach Zachodnich. Witold Lorentowicz żyje nadal, jest ludowym rzeźbiarzem i mieszka w Polakąch koło Kotunia. 
warsztat kołodziejski. Następnie przybyła do Dobrówki Stanów sześcioosobowa rodzina Wąsowskich: ojciec był dyplomowanym szewcem miejskim, a w pracy wspomagali go trzej dorośli synowie: Edward, Teodor i Jan. Pochodzili prawdopodobnie z obszarów zachodniego Mazowsza.

Jesienią 1940, albo wiosną $1941 \mathrm{r}$. przybyło do naszej wsi małżeństwo Chudziaków wysiedlonych spod Wielunia z pięciorgiem małych dzieci. W tym samym mniej więcej czasie pojawiły się dwie kilkuosobowe, spokrewnione ze sobą rodziny Łopatków i Dyduchów, obie wysiedlone z Gilowic koło Żywca. Jesienią 1941 r. przybyły natomiast dwie rodziny z obszarów wschodnich. Jedną $\mathrm{z}$ tych rodzin było małżeństwo Bożyków, które osiadło w domostwie pozostawionym przez Żyda, młynarza przebywającego już w siedleckim getcie. Bożyk wyremontował młyn wyposażony w stary motor zniszczony wiosną $1940 \mathrm{r}$. wybuchem materiałów pędnych. Ci nowi użytkownicy młyna zatrudnili motorniczego, Kazimierza Zamyłkę. Był to inwalida wojenny, raniony w obie nogi jesienią $1939 \mathrm{r}$. Zamieszkał wraz z żoną Zofią i synem Zbigniewem (obecnie lekarz w Koszalinie) w domu Czesława i Albiny Wrzosków. Wypada ponadto wspomnieć o Stanisławie Braulińskim, który był pozbawiony majątku ziemskiego, usytuowanego na tak zwanym Wymyślu koło Latowicza i przeniósł się do wsi Dąbrówka Stany wraz z żoną i czterema synami, w tym dwóch dorosłych. Rodzina Stelmachów z Warszawy szukała natomiast na wsi możliwości latwiejszej egzystencji.

Najbardziej aktywnymi osobami w gronie tych, którzy znaleźli się w gminie Skórzec, okazali się wszakże dwaj nauczyciele, a mianowicie kierownik czteroklasowej szkoły w Dąbrówce Stanach i kierownik czteroklasowej szkoły w Czerniejewie. Kierownkiem szkoły stańskiej był porucznik rezerwy Jan Kazimierz Krupa, a czerniejewskiej podporucznik rezerwy Wacław Domagała ${ }^{49}$.

Pierwszy okres okupacyjnych dziejów Południowego Podlasia, od jesieni 1939 do jesieni 1941 r., upływał na ogół pod znakiem zastoju i takich zachowań, w których chodziło o przystosowanie się do nowych, jakże trudnych warunków egzystencji. Warunki codziennego życia były uzależnione od nieustannego osobistego zagrożenia, a także od niezwykle dokuczliwego niedostatku i narastającej drożyzny artykułów żywnościowych. Obszar wyznaczony przez zwycięskiego wroga jako terytorium Generalnej Guberni, został zniszczony podczas działań wojennych. Był zaś eksploatowany ekonomicznie w sposób zbrodniczy przez okupanta, który narzucił olbrzymie

49 O roli poruczników Krupy i Domagały szerzej w dalszych fragmentach niniejszego artykułu. 
obowiązkowe dostawy zboża, ziemniaków, żywca, tłuszczów, mleka i nabiału. Taki natomiast artykuł żywnościowy jak cukier, był albo niezwykle. drogi, albo prawie zupełnie niedostępny. Troska o zaspokojenie potrzeb codziennego życia stała się więc nieodłącznym towarzyszem mieszkańców całej udręczonej krainy, w tym także obszarów Południowego Podlasia. Znalazło się jednak wielu takich, którzy nie zapominali o obowiązkach wobec społeczenistwa i zniewolonej ojczyzny.

Do zestawu bardzo ważnych obowiązków wobec społeczeństwa, a tym samym i ojczyzny, należała troska o sprawy oświaty oraz szkolnictwa. Intensywne zabiegi o wznowienie legalnego nauczania w siedleckich szkołach średnich, czyli w gimnazjach oraz liceach, były podejmowane przez miejską Komisję Dyrektorów Szkół Średnich. Ta komisja występowała z inicjatywy wybitnego pedagoga siedleckiego, doktora filozofii Stanisława Rutkowskiego, który od 1923 r. był dyrektorem Gimnazjum i Liceum im. Bolesława Prusa w Siedlcach. Wstępne zabiegi rozpoczęły się po upływie kilku dni od zajęcia Południowego Podlasia przez wojska niemieckie. Zostały jednak przerwane, gdy do Siedlec wkroczyły oddziały Armii Czerwonej, a były wznowione na przełomie pierwszej i drugiej dekady października 1939 r. Doszło wówczas do spotkania wspomnianej Komisji z przedstawicielem niemieckiej Komendy Miasta, która zainstalowała się w gmachu usytuowanym na rogu ulic Józefa Piłsudskiego i Świętojańskiej, a należącym do Narodowego Banku Polskiego ${ }^{50}$.

Spotkanie Komisji z niemieckim komendantem miasta zakończyło się niby częściowym powodzeniem. Zapowiedział on, że wszystkie szkoły, z wyjątkiem żydowskich i Liceum Pedagogicznego, będą czynne. Licząc się z naleganiami Komisji zdecydowal się tylko na takie ustępstwo, że uznał także możliwość funkcjonowania Liceum Pedagogicznego „na własną odpowiedzialność" dyrektor Agaty Ciskówny, a ponadto uzależnił tę możliwość od decyzji starosty Friedricha Gerckego. Te przyzwolenia, jakie złożył przedstawiciel wojskowej Komendy Miasta, nie odpowiadały jednak założeniom niemieckiego systemu okupacyjnego w Generalnej Guberni. Już 31 października 1939 r. ukazało się oficjale zarządzenie doktora Franka, który stwierdził: „Nazwa gimnazjum lub liceum dla szkół fachowych jest zakazana" ${ }^{51}$.

50 A. Zawadzka, Szkola siedlecka w okresie okupacji hitlerowskiej 1939-1944, Warszawa 1986, s. 64 .

51 Zarządzenie generalnego Gubernatora Hansa Franka z 31 października 1939 r., w: „Przegląd Historyczno-Oświatowy” 1947, nr 1, s. 161; por. także: L. Koper, 75 lat I Liceum Ogólnoksztalcqcego im. B. Prusa w Siedlcach. 192.3-1998, Siedlce 1998, s. 29. 
Dalszą działalność usiłował jednak podejmować dyrektor Rutkowski wspomagany przez ofiarne grono pedagogiczne. Okazało się to jednak nieınożliwe, gdy władze niemieckie zdecydowały się na podstępne przeciwdzialanie. Zostało ono zapoczątkowane 1 grudnia 1939 r. kontrolowanyın pożarem, który był wywołany na strychu w gmachu starostwa, czyli w kamienicy usytuowanej przy ulicy Floriańskiej i mającej wspólną ścianę szczytową z budynkiem Gimnazjum i Liceum in. Bolesława Prusa. Ten sztuczny pożar został oczywiście błyskawicznie ugaszony, ale w szkole pojawil się niezwłocznie wysoko postawiony funkcjonariusz niemieckiej policji i polecił zwołanie Rady Pedagogicznej. Zachowywał się w sposób bezczelny i brutalny. Groził profesorom i wykrzykiwal, że ten pożar, to zamach na bezpieczeístwo władz niemieckich. Nakazał natychmiastowe zamkniecie szkoły i zapowiedzial buńczucznie, że zostanie zamknięta po wieczne czasy 52 .

Po tych wydarzeniach w Siedlcach oficjalnie funkcjonowały już tylko szkoły powszechne, określane obecnie jako podstawowe, a także kilka trzyklasowych szkół zawodowych, między innymi rolnicza, rzemieślnicza i żeíıska szkoła krawiecka. W dniu 1 września 1940 r. doktor Stanisław Rutkowski otworzył natomiast za zgodą niemieckich władz szkolnych Kursy Przygotowawcze do Szkół Zawodowych i pod ich firmą był realizowany program nauczania niższych klas ogólnokształcącej szkoły średniej. Ta nauka odbywała się w starym parterowym drewnianym domu, usytuowanym przy ulicy Piłsudskiego, naprzeciw wylotu ulicy 22 Pułku Piechoty. Do głównych przeszkód w procesie nauczania podejmowanego przez tę szkołę, oprócz ogromnej ciasnoty, należało permanentne zagrożenie ze strony niemieckich władz szkolnych i policyjnych, a także to, że od marca 1941 r. dyrektor Rutkowski został umieszczony na stałej liście zakładników i przebywał kilkakrotnie w tymczasowym areszcie. Zaczął się więc ukrywać i zamieszkał na Saskiej Kępie w Warszawie u córki Krystyny Zaremskiej.

Dyrektor Rutkowski pracowal wówczas jako ekspedient sklepu żelaznego, a jednocześnie działał w tajnym nauczaniu na terenie Warszawy ${ }^{53}$. Pro-

52 Ibidem, passim. Fakty przytoczone przez autora zostały oparte na osobistych wspomnieniach dyrektora szkoły Stanisława Rutkowskiego, spisanych przez autora niniejszego artykułu w maszynopisie mającym około 40 stron; rękopis w posiadaniu autora niniejszego artykułu, jednym egzemplarzem dysponuje rodzina dyrektora Rutkouskiego, drugi otrzymała aktualna dyrekcja szkoły za pośrednictwem przewodniczącego Komitetu Organizacy jnego Zjazdów Absolwentów sędziego Witolda Oknińskiego, a trzeci rodzina dyrektora przekazała emerytowanemu dyrektorowi żeńskiego Gimnazjum i Liceum im. Królowej Jadwigi, czyli Anieli Zawadzkiej (op. cit., s. 61).

53 M. Wrzosek, [biogram Stanisława Rutkowskiego], Polski Slownik Biograficzny, T. $33 / 2$, 1991 , z. 137 , s. $242-243$. 
cesem tajnego nauczania w Siedlcach zaczął natomiast kierować profesor polonistyki Ignacy Wojewódzki, który występował jako tymczasowy dyrektor tajnego siedleckiego Gimnazjum i Liceum im. Bolesława Prusa. Po wyjeździe dyrektora Rutkowskiego do Warszawy nastąpiło zamknięcie Kursów Przygotowawczych do Szkół Zawodowych i dalszy proces tajnego nauczania w Siedlcach trwał w ramach tak zwanych Tajnych Kompletów Nauczania, a lekcje odbywały się w prywatnych mieszkaniach. Takie kursy były istotnym przejawem działalności podziemnego paístwa polskiego i stanowiły ważną formę obrony tożsamości narodowej.

Nastąpiło również daleko idące ograniczenie zakresu nauczania w szkołach powszechnych (podstawowych). Zapowiedź takiego ograniczenia była zawarta już w wypowiedzi skierowanej podczas wspomnianego spotkania Komisji Dyrektorów Szkół Średnich z przedstawicielem niemieckiej Komendy Miasta. Stwierdził on, że z programów szkół powszechnych zostaje usunięta nauka historii oraz geografii, zaś nauczanie języka polskiego będzie polegało na ćwiczeniu gramatyki i zasad wypowiadania się na piśmie, a jako nowy obowiązujący przedmiot nauczania został wymieniony język niemiecki ${ }^{54}$.

O treści zapowiedzianych decyzji zostali potem poinformowani kierownicy szkół powszechnych. Nie odbywały się więc lekcje historii i geografii, a wyłączną pomoc w nauce języka polskiego oficjalnie miał stanowić miesięcznik "Ster”, redagowany w Krakowie pod ścisłą kontrolą niemieckich okupacyjnych władz szkolnych ${ }^{55}$. Neutralizacja tych zakazów zależała oczywiście w dużym stopniu od dostępu do zakazanej książki i od nauczycieli. Sześcioklasowa szkoła w Skórcu funkcjonowała w wyjątkowej, dość korzystnej sytuacji. Wynikało to po części z takich okoliczności, że duchownymi w parafii Kościoła rzymskokatolickiego byli ojcowie Zgromadzenia Księży Marianów, zaś w ich dość zasobnej bibliotece znajdowały się książki wybitnych pisarzy polskich, a po części także przekłady obcych autorów.

Lekcje języka polskiego $\mathrm{w}$ klasach wyższych niż czwarta prowadziła wspominana już Feliksa Wąsikowa. Jej lekcje były dla uczniów niezapomnianym przeżyciem. W nauczaniu nie stosowała się do zaleceń okupacyjnych władz szkolnych. Z tego też względu miesięcznik "Ster” był wykorzystywany w minimalnym stopniu. Podstawę nauczania stanowiła zaś literatura piękna, czerpana w miarę obficie z biblioteki parafialnej. Dzięki zaleceniom

54 A. Zawdzka, op. cit., s. 65.

55 Osobiste wspomnienia autora niniejszego artykułu. 
pani Wąsikowej dziatwa V, VI i VII klasy zapoznawała się z polską literaturą piękną, czytała Mickiewicza, Sienkiewicza Prusa, Konopnicką i innych klasyków. Lekcje pani Wąsikowej były przesycone oddziaływaniem patriotycznym. Na przedwiośniu 1942 roku w roli lektora wystąpiła sama pani pedagog. Podczas kolejnej lekcji przeczytała wówczas Redutę Ordona, poetycki utwór Adama Mickiewicza.

Wydarzeniem godnym upaniętnienia była też pewna lekcja $\mathrm{z}$ jesieni 1942 r. Cel dydaktyczny tej lekcji, a raczej wykładu trwającego prawie dwie godziny, polegał na zapoznaniu uczniów VI klasy z dziejami narodowymi. Takie wystąpienie zapoczątkowało sprostowanie wypowiedzi jednego z uczniów, który stwierdził, że Polska przed odzyskaniem niepodległości w 1918 r., znajdowała się przez 123 lata w niewoli. Uczniowie słuchali z zapartym tchem, jak pani Wąsikowa dowodziła, że $\mathrm{w}$ istocie nie była to niewola $w$ pełnym tego słowa znaczeniu, ponieważ naród polski nigdy nie pogodził się z jej jarzmem. Podkreślała $\mathrm{z}$ naciskiem, że utrata niepodległości nie była też zjawiskiem ciągłym, bo okres zniewolenia przerywały niepodległościowe zrywy Polaków (epopeja Legionów Polskich generała Henryka Dąbrowskiego, Księstwo Warszawskie, powstanie listopadowe, powstanie styczniowe). Argumenty pani Wąsikowej były ujęte w sposób tak przystępny, że zostały przez uczniów zrozumiane i wywarły na nich duże wrażenie. Miały znaczenie emocjonalne, ponieważ wokół rozprzestrzeniały się mroki upiornej okupacji ${ }^{56}$.

Postępowanie magister Wąsikowej było bardzo ryzykowne, ponieważ w tej wsi gminnej, jaką był Skórzec, znajdował się kilkuosobowy posterunek niemieckich żandarmów. Oni nie zaprzątali jednak swoich głów sprawami szkolnymi, wypełniali bowiem zadania związane bezpośrednio z podtrzymywaniem systemu okupacyjnego i dostawą kontyngentów narzucanych polskim rolnikom. Dbali też pilnie o własne bezpieczeństwo, a także o swoją osobistą wygodę. Lubili dobrze podjeść, a także popić i dlatego dość często odwiedzali sołtysów poszczególnych wsi, a ci nie żałowali samogonu, bo zdawali sobie sprawę z tego, że to najprostszy sposób, aby zapewnić mieszkańcom upragniony spokój.

Na przełomie czerwca i lipca 1943 r. magister Wąsikowa odeszła ze stanowiska nauczyciela szkoły powszechnej, a we wrześniu tegoż roku skupiła się wyłącznie na obowiązkach organizatora, kierownika i profesora kompletu tajnego nauczania na poziomie szkoły średniej. Pierwsza grupa uczniów, 
którzy pod kierunkiem pani Wasikowej rozpoczęli naukę w zakresie I klasy gimnazjum ogólnokształcącego, składała się z trzech dziewcząt. Były to: Danuta Kaniówna (córka urzędnika gminnego), Barbara Marciszewska (bratanica komendanta iniejscowego posterunku policji granatowej) i Janina Taraszewska (córka rolnika ze wsi Cisie Zagródzie) ${ }^{57}$. Grupa wymienionych uczennic przerabiała materiał I klasy w roku szkolnym 1942/1943.

W następnym roku szkolnym działalność tajnego kompletu magister Wąsikowej była już znacznie większa. Wspomniane trzy uczennice zaczęły przerabiać materiał II klasy, a naukę na poziomie I klasy rozpoczęła nowa grupa mająca już 10 dziewcząt i 3 chłopców. Ze Skórca pochodziły: Zofia Barejówna, Janina Guzkówna, Helena Ługowska, Maria Mikusówna i Urszula Świetlikówna (córka polskiego policjanta zamordowanego w Oświęcimiu); z Dąbrówki Ług Janina Potyrówna i Henryka Skaruøówna, z Boroszkowa Dominika Weredówna i bardzo uzdolniony Władysław Sadokierski (po latach absolwent warszawskiej Akademii Medycznej i lekarz w Białymstoku); ze wsi Cisie Zagrudzie Krystyna Tarasiukówna; z Dąbrówki Stanów Krystyna Dąbrowska, Helena Zeınłówna, Jerzy Tkacz (potem absolwent warszawskiego Liceum im. Władysława IV, pracownik służb dyplonatycznych) i Mieczysław Wrzosek (historyk, po latach profesor Uniwersytetu w Białymstoku i warszawskiej Akademii Obrony Narodowej) ${ }^{58}$.

Powiększyło się również grono nauczycieli. Magister Wąsikowa uczyła języka polskiego, laciny, historii i geografii. Nauczycielem języka niemieckiego była Józefa Tomaszewska, lekcje matematyki prowadził Jan Lipiński, a lekcje religii miał z nami przeor klasztoru O.O. Marianów, absolwent Uniwersytetu Warszawskiego, magister historii, ksiądz Jan Seferyński. Był słuchaczem tego samego roku studiów, co profesor Aleksander Gieysztor ${ }^{59}$. Nauce na tajnym komplecie towarzyszyło poczucie strachu, zwłaszcza od tego momentu, gdy za otwartym oknem domu Aleksandra Barei, w którym odbywały się nasze lekcje, stanął funkcjonariusz miejscowego posterunku niemieckiej żandarmerii. Obserwował nas przez dłuższą chwilę, a odchodząc powiedział niby „gut, gut”. W ostatniej dekadzie czerwca 1944 r. uczniowie tajnego kompletu magister Wąsikowej zostali przeegzaminowani przez profesorów tajnego, siedleckiego Gimnazjum i Liceum im. Bolesława Prusa. Egzaminatorami byli; polonista Ignacy Wojewódzki i matematyk Czesław

57 J.w.

58 .J.w.

59 Ustna relac.ja księdza Jana Seferyńskiego z 1958 r. 
Burczak. Egzamin wypadł pomyślnie i uczestnicy tajnej edukacji stali się uczniami II klasy gimnazjalnej ${ }^{60}$.

Najważniejszym przejawem zmagań z niemicckim okupantem był jednak opór zbrojny. Wstępne poczynania miały charakter spontaniczny i polegały na ukrywaniu broni, która pozostała na pobojowiskach i miejscach postoju polskich jednostek wojskowych we wrześniu 1939 r. Największa jej ilość została zabezpieczona na terenie takich gmin powiatu siedleckiego, jak Domanice, Mokobody, Skórzec, Wodynie i Żeliszew ${ }^{61}$. Już wówczas, a zwłaszcza w roku następnyın, na terenie powiatu siedleckiego zaczęły działać liczne konspiracyjne zrzeszenia polityczne oraz związane z nimi zalążki organizacji wojskowych. Sprawy te wymagają wszakże szerokiego ujęcia i były już omawiane w licznych, solidnych opracowaniach. Nie będą więc stanowić tu przedmiotu dalszych, bardziej szczegółowych rozważań, ponieważ chodzi teraz głównie o przedstawienie wydarzeń dotyczących Związku Walki Zbrojnej - Armii Krajowej w gininie Skórzec. Wypada tylko zaznaczyć, że już jesienią 1939 r., ukształtował się w Siedlcach lokalny ośrodek dyspozycyjny Służby Zwycięstwu Polski (SZP) i przystąpił do konspiracyjnej działalności pod kierunkiem porucznika rezerwy Juliana Ochnika, który w okresie przedwojennym był powiatowym komendantem Związku Obrońców Ojczyzny i Związku Rezerwistów. Niebawem organizacja ta stała się terenowym ogniwem Związku Walki Zbrojnej, funkcjonującego w okresie późniejszym jako ZWZ-AK ${ }^{62}$.

Pierwszym komendantem siedleckiego obwodu Armii Krajowej (kryptonimy „Sowa”, „Jesion”) był kapitan Bolesław Dziewulski, pseudonimy "Żuraw”, „Młynarski” (od listopada 1939 do 27 listopada 1940). Został jednak ujęty przez funkcjonariuszy niemieckiego aparatu policy.jnego i zamordowany w warszawskim więzieniu. Jego następcą był podpułkownik dyplomowany Jan Kąkolewski, pseudonim „Zaremba” (od grudnia 1940 do 25 maja 1941), ale został odwołany z powodu zagrożenia aresztowaniem. Potem obowiązki komendanta obwodu przejął major Marian Zawarczyński (pseudonimy: „Mir”, „Ziemowit”) i sprawował je od czerwca 1941 do listopada 1944. Został ujęty przez NKWD, był postawiony przed sądem polowym wojsk I Frontu Białoruskiego. Wolności nie odzyskał ${ }^{63}$.

60 Osobiste wspomnienia autora niniejszego artykułu.

61 H. Piskunowicz, op. cit., s. 3.

62 Ibidem, s. 5 i n.

63 H. Piskunowicz, op. cit., s. 5-6, 57. 
W okresie początkowym konspiracyjna działalność ZWZ-AK w powiecie siedleckim koncentrowała się na sprawach związanych z ukształtowaniem obwodowej komendy i na rozpoznaniu możliwości rozbudowy terenowych struktur organizacji. Chodziło zwłaszcza o nawiązanie kontaktu w poszczególnych gminach z osobami mającymi już wyszkolenie wojskowe. Te zabiegi trafiały w gminie Skórzec na grunt podatny, ponieważ kierownicy dwóch szkół powszechnych byli oficerami rezerwy. Chodzi tu konkretnie o podporucznika Wacława Domagałę, który kierował czteroklasową szkołą powszechną we wsi Czerniejew (osada usytuowana na północno-zachodnich krańcach gminy Skórzec). Drugi zaś to porucznik Jan Kazimierz Krupa, który był kierownikiem czteroklasowej szkoły w Dąbróce Stanach i mieszkał w domu małżeństwa Albiny i Czesława Wrzosków ${ }^{64}$. Mieszkanie porucznika Krupy było wykorzystywane jako punkt kontaktowy, z czego właściciele domu nie zdawali sobie zupełnie sprawy. Bardzo częstym gościem lokatora Wrzosków był podporucznik Wacław Domagała. Często zachodził do niego również konspiracyjny żołnierz Karol Bareja „Bachacz”, człowiek obdarzony odwagą niezwykłą, graniczącą z zuchwalstwem. Niekiedy pojawiał się również porucznik Stanisław Dąbrowski, starszy brat Ludwika, który był strażnikiem więziennym w Siedlcach i należał również do AK. Obaj porucznicy (Krupa i Dąbrowski) pełnili w strukturach AK jakieś ważne funkcje, ale poza terenem obwodu siedleckiego; porucznik Krupa zapewne w obwodzie garwolińskim, a Stanisław Dąbrowski chyba w obwodzie łukowskim ${ }^{65}$.

Istotną rolę odgrywało również to, że spore grono światlejszych mieszkańców Dabrówki Stanów miało dość regularny dostęp do tajnej prasy. Jej egzemplarze dostarczał warszawski listonosz Wacław Zabłocki, brat Stanisława, dalszego sąsiada Wrzosków. W sąsiedniej wsi Dąbrówce Niwce funkcjonowal natomiast jeden $\mathrm{z}$ kilku najważniejszych punktów kontaktowych obwodu siedleckiego. Konspiracyjne spotkania odbywały się tam w domu braci Obłozów, Eugeniusza i Lucjana „Rawicza” ${ }^{66}$. Obłozowie byli współwłaścicielami sporego majątku ziemskiego, mającego około 90 morgów ziemi ornej.

Do grona najaktywniejszych organizatorów siedleckiego obwodu ZWZ-AK, oprócz oficerów zawodowych, należeli nauczyciele. W grupie tych zaś

64 Byli to rodzice autora niniejszego artykułu.

65 Osobiste wspomnienia autora niniejszego artykułu.

66 H. Piskunowicz, op. cit., s. 5. Ta wzmianka pokrywa się z tym, co autor niniejszego artykułu zapamiętał z kilku przypadkowych wypowiedzi Jana Kazimierza Krupy, który napomykał czasami, że odwiedzał Obłozów. 
najbardziej rzutkich i czynnych konspiratorów wyróżniał się już wspominany podporucznik rezerwy Wacław Domagała, pseudonim „Piątek”. W latach 1940-1942 udzielal się on głównie jako dowódca sześcioosobowego patrolu wystawionego przez formację specjalną, jaką był Związek Odwetu w organizacyjnych strukturach $\mathrm{AK}^{67}$. Potem bywał dość często organizatorem zbrojnych akcji odwetowych, ale główne jego zadania wynikały z obowiązków komendanta tych sił AK, jakie zorganizował na obszarze gminy Skórzec; czyli na terenie placówki kryptonim „Kret”. Siły znajdujące się w dyspozycji podporucznika Domagały podlegały komendzie Ośrodka II Żeliszew, kryptonimy „Żelbeton” i „Ogródek”, a na czele zespolonych sił gminy Skórzec i gminy Żeliszew stał kierownik żeliszewskiej szkoły powszechnej porucznik rezerwy Jan Koryciński, pseudonim „Krop” 68.

Z zachowanych raportów wynika, że komenda siedleckiego obwodu Armii Krajowej (kryptonimy „Sowa”, „Jesion”), na dzień 1 stycznia $1943 \mathrm{r}$. miała 37 plutonów żołnierzy, w tym 3. pluton podporucznika Wacława Domagały "Piątka”. Zastępcą dowódcy tego pododdziału, mającego wówczas 59 zaprzysiężonych, był plutonowy "Soroka" ${ }^{69}$. Następnie, siły znajdujące się w dyspozycji komendanta Placówki „Kret” znacznie wzrosły, ale dokładnej liczby jego podkomendnych w okresie przed akcją „Burza”, czyli w trzeciej dekadzie lipca 1944 r., nie udało się ustalić.

Podporucznik Damagała jako organizator placówki „Kret” występował zapewne od wiosny 1942 r. Takie przypuszczenie znajduje swoje potwierdzenie w biogramach paru konspiracyjnych żołnierzy AK gminy Skórzec, między innymi Wacława Czeluścińskiego ze Skórca, pseudonim „Lis” i Józefa Feliksa Jastrzębskiego z Dąbrówki Stanów, pseudonim „Sosna” 70 . Żołnierze placówki „Kret” w szeregi konspiracyjnej AK byli przyjmowani indywidualnie przez podporucznika Domagałę ( „Piątka”), który ich osobiście zaprzysięgal. W Dąbrówce Stanach pozyskał 14 członków, głównie wiosną i latem 1942 r. Byli to: Karol Bareja „Bachacz”, Marian Cabaj, Marian Dąbrowski „Mundzio” i „Żwirek”, Marian Długosz, Władysław Izdebski, Jan Jastrzębski „Śmiałek” i starszy jego brat kapral Józef Feliks Jastrzębski „Sosna”, Wiktor Jastrzębski i jego młodszy brat kapral Józef Jastrzębski, Julian Rajewski, kapral Antoni Sitarz „Zagoda”, starszy wachmistrz ruszni-

67 A. Charczuk, op. cit., s. 423.

68 H. Piskunowicz, op. cit., s. 8 i n.

69 Ibidem, s. 12; nazwisko tego konspiratora nie zostało jednak ustalone.

70 Podlasie w walce. Światowy Zuriqzek Zolnierzy Armii Krajowej Obwód Siedlce. Biogramy Kola Skórzec, oprac. Barbara Arcichowska, Siedlce br. r. wyd., s. 5 i s. 7. 
karz Kazimierz Zanyłko „Koń” i Lucjan Żukowski „Drapak”“1. Byli niemal wszyscy rolnikami, a tylko wachmistr\% Zamyłko przed wybuchem wojny służył w Równem na Wołyniu jako podoficer zawodowy. Potem uczestniczył w jesiennej kampanii polsko-niemieckiej, został raniony w obie nogi i był inwalidą ${ }^{72}$.

W gininnej wsi Skórcu mieszkało co najmniej jedenastu członków AK. Najwyższymi stopniami dysponowali dwaj z nich, a mianowicie lekarz weterynarii podporucznik Ludwik Ossowski pseudonim „Doktor” i jego brat kıpral podchorąży Henryk Ossowski pseudonim "Osa" 73. Czynnymi członkami byli ponadto: Szymon Barabasz Śmiały”, Edward Bareja „Edzio”, Waclaw Czeluściński „Lis”, Edward Karczmnarek „.Cygan”, Mieczysław Olszewski „Ryś”, Mieczysław Roman „Sęp”, Czesław Olszewski „Czesiek” i Stanisław Wiechetek (pseudonim nieznany) ${ }^{74}$. Członkiem AK, sprawa godna uwagi, był także komendant posterunku policji granatowej w Skórcu Józef Marciszewski. Pochodził z Igaí pod Siedlcami ${ }^{75}$.

Największą aktywność okazywali wszakże mieszkańcy wsi Dąbrówka Niwka, zachowującej jeszcze cechy szlacheckiego zaścianka, zaliczanego w gminie Skórzec do grupy osad najmniejszych, a jednocześnie najbardziej zamożnych. Do grona tych, którzy zasilili gminną jednostkę AK, należeli tam: Edward Burgs „Wojtek”, Henryk Burgs, Jan Burgs „Bór”, Marian Burgs „Lis”, Marian Burgs „Bąk”, Stefan Dyınowski, Józef Jastrzębski „Sarna”, Stanisław Jastrzębski „Wis”, Lucjan Krasnodębski „Krupa”, Eugeniusz Obłoza, Lucjan Obłoza "Rawicz”, Roman Okniński, Seweryn Okniński, Józef Radzikowski „Wolf”, Jan Świerczewski, Tadeusz Świerczeski i Sylwester Świerczewski ${ }^{76}$. Wypada ponadto wymienić zamieszkałego w Dąbrówce Niwce Franciszka Krasnodębskiego, którego komendant Pla-

71 Ustna relacja złożona przez Jana Jastrzębskiego 19 lutego 2005 r.

72 Jest wymieniany przez Henryka Piskunowicza jako podoficer Ośrodka II Żeliszew, kryptonim Żelbeton” i „Ogródek” (op. cit., s. 8). Faktycznie był podoficerem Placówki „Kret” w Skórcu. Podczas okupac.ji pracownik młyna w Dąbrówce Stanach. Mieszkał wraz z żoną Zofią i synem Zbigniewem (po wojnie lekarz koszaliński) w domu małżeństwa Albiny i Czesława Wrzosków. Osobiste wspomnienia autora niniejszego artykułu.

73 H. Piskunowicz, op. cit., s. 56.

74 Podlasie $w$ walce..., passim.

75 Osobiste wspomnienia autora niniejszego artykułu.

76 Podlasie w walce..., passim; J. Pawlak, Akcja kryptonim „P-1.05”, w: Arnia Krajowa nu środkowej i poludniowej Lubelszczyźnie i Podlasiu. Materialy sesji naukowej KUL, 24-25 IX 1985 r., pod red. Tomasza Strzembosza, Lublin 1993, s. 470; także ustna relacja Antoniego Burgsa (syn Henryka), złożona 11 stycznia 2005; ponadto ustna relacja złożona przez Elżbietę Kalitową, z domu Świerczewską, rodzoną siostrę zmarłego Sylwestra, a cioteczną siostrę autora niniejszego artykułu. 
cówki „Kret” nie mógł zaprzysiąc z powodu zbyt młodego wieku, ale znalazł się w szeregach placówki gminy Kotuń, Ośrodek II Żeliszew, kryptonim Żelbeton" i "Ogródek" 77.

W Boroszkowie, osadzie sąsiedniej i jeszcze mniejszej niż Dąbrówka Niwka, członkami AK byli zaś: Edmund, Ferdynand, Mieczysław i Seweryn Burgsowie oraz Zenon Lorentowicz, który pochodził z Czyżewicz za Bugiem $^{78}$. Na podstawie dostępnych przekazów materiałowych można również ustalić, że żołnierzami Placówki „K ret” byli: w Dąbrówce Wyłazy Wincenty Filipowicz „Kartka” i Stanisław Wyczółkowski „Stały”; w Dąbrówce Ług” Jan Kokoszka „Kurek” i Edmund Rudnicki „Krokiew”; we wsi Nowaki Kazimierz Piekart „Sęp 2”; w Czerniejewie kapral Antoni Dziewulski, „Wisła”, Bronisław Szostek i Feliks Szostek, a we wsi Gołąbek Eugeniusz Karczewski „Dobraczyński”, Kazimierz Prokurat „Zuch”, Marian Prokurat „Sarna” i Józef Pucyk „Grab” 79.

Główne zadania Placówki „Kret”, jako lokalnego, czyli podstawowego ogniwa sił Armii Krajowej, wynikały z obowiązku uczestnictwa w walce bieżącej i w przygotowaniach do ogólnego powstania zbrojnego. W roli centralnego organizatora sił przeznaczonych do walki bieżącej, a także koordynatora tej walki, występował początkowo Związek Odwetu. Był to organ specjalny, powołany przy Komendzie Głównej ZWZ na podstawie rozkazu wydanego przez generała Kazimierza Sosnkowskiego w kwietniu 1940 r. Po zmianach organizacyjnych, do których doszło na przełomie lat 1942 i 1943, cały zakres tych obowiązków przejęło natomiast Kierownictwo Dywersji (Kedyw).

Obowiązki sił podporządkowanych Związkowi Odwetu, a potem znajdujących się w dyspozycji Kedywu, polegały na dążeniu do osłabienia wojennego potencjału Niemiec i na realizacji zadań związanych z koniecznością podejmowania samoobrony oraz akcji odwetowych. W działaniach dotyczących wojennego potencjału chodziło o utrzymywanie niskiej wydajności pracy i ograniczanie w ten sposób produkcji przemysłowej, a także o niszczenie zapasów paliwa, materiałów wojennych oraz produktów żywnościowych gromadzonych w magazynach znajdujących się pod bezpośrednią kontrolą niemieckich sił okupacyjnych. W działaniach związanych z samoobroną i akcjami odwetowymi chodziło natomiast głównie o powstrzymywanie okupacyjnego terroru.

77 Ustna relacja Antoniego Burgsa z 12 kwietnia 2005 r.

78 Tenże.

79 Podlasie $w$ walce..., passim. 
Uczestnikami destrukcyjnych poczynaí w dużych zakładach przemysłowych stawały się zespoły sabotażowe, a tam, gdzie takich zakładów nie było, działały patrole dywersyjne. Centralnym koordynatorom walki bieżącej, organizowanej najpierw przez komendę Związku Odwetu, a potem przez sztab Kedywu, podlegały odpowiednie ogniwa terenowe. Siedleckim komendantem sil organizowanych pod patronatem Związku Odwetu od wiosny 1940 do stycznia 1942 r. był porucznik rezerwy Adam Kompowski „Adam”. Jego następcą zostal major Jan Sasin „Kopka” i do czerwca 1944 r. kierował działaniami na podstawie uprawnień, jakimi dysponowal, a także według poleceń otrzymywanych drogą służbową z komendy Kedywu ${ }^{80}$.

Wstępne ujęcie zasad, według których miała być podejmowana zbrojna walka bieżąca, zawieral już projekt statutu Służby Zwycięstwa Polski (SZP). W dokumencie tym, datowanym 6 stycznia 1940 r. i przesłanym do zatwierdzenia generałowi Władysławowi Sikorskiemu jako naczelnemu wodzowi Wojska Polskiego przez generała Michała Karaszewicza Tokarzewskiego, znajdowała się wzmianka o „drużynach specjalnych”, które miały być tworzone w konspiracyjnych siłach zbrojnych przy jednostkach tak niskiego szczebla, jak terenowe placówki podlegające komendantom powiatowym $^{81}$.

W okresie pierwszym, gdy walką bieżącą kierowała komenda Związku Odwetu, porucznik Kompowski dysponował czterema patrolami, które były tworzone od wiosny 1940 r. Pierwszym sześcioosobowym patrolem dowodził podporucznik Wacław Domagała „Piątek”. Na czele dwóch następnych, mających łącznie czternastu również starannie dobranych bojowników, stał podporucznik Wacław Węgrowski „Gałązka”, a komendantem czwartego, utworzonego na przełomie listopada i grudnia 1940 r., był podchorąży rezerwy Jerzy Lorkiewicz „Benek” 82.

Jesienią 1942 r. za przebieg walki bieżącej zaczynały już jednak odpowiadać struktury Kedywu. Odbywała się też reorganizacja tych struktur w siedleckim obwodzie Armii Krajowej. W listopadzie tegoż roku do podejmowania takiej walki była więc powołana specjalna grupa sabotażowo-dywersyjna, a jej komendantem został podporucznik rezerwy Jerzy Kurowski

80 H. Piskunowicz, op. cit., s. 15; A. C'harczuk, op. cit., s. 188.

81 Polskie Sily Zbrojne $w$ drugiej wojnie światowej, t. 111, Amnia Krajowa, Londyn 1950, s. 100. Tekst wspomnianej wzmianki: „Statut przewiduje organizowanie drużyn ochronnych i bojowych przez placówki oraz drużyn specjalnych - szturmowych, łączności, administracyjno-gospodarczych i sanitarnych - przy dowództwach wszystkich szczebli od głównego do placówki.

82 A. Charczuk, op. cit., s. 423. 
„Nałęcz". W maju 1943 r. grupa ta miała już jednak nowego komendanta. Był nim porucznik „Komandor" ${ }^{83}$. Miał on w swej dyspozycji cztery patrole, którymi dowodzili: plutonowy Zdzisław Skowroński „Karaś”, kapral Jan Ponikowski „Czort”, kapral „Wicher” i podporucznik rezerwy Stanisław Bielecki „Zawada" ${ }^{84}$. We wrześniu tegoż roku doszło do poważnego wzmocnienia siedleckiej grupy sabotażowo-dywersyjnej, ponieważ była ona zespolona z grupą sabotażowo-dywersyjną Tajnej Organizacji Wojskowej (TOW), a zwierzchnikiem tych połączonych sił został major Jan Sasin „Kopka”. W czerwcu 1944 r. major Sasin zostal odwołany do Sokołowa Podlaskiego. Komendę nad całym oddziałem siedleckich sił Kedywu przejął wówczas podporucznik Jerzy Krukowski „Nałęcz”, a stanowisko referenta dywersyjnego otrzymał podporucznik Wacław Domagała "Piątek”, który był nadal komendantem Placówki „Kret”.

Znaczna część patroli należących do tej właśnie jednostki dywersyjno-bojowej, przebywała w poszczególnych ośrodkach terenowych, a jeden $\mathrm{z}$ nich był zorganizowany w ośrodku Żeliszew (kryptonim „Żelbeton” i „Ogródek"). Jego komendantem był zaś kapral podchorąży Wiesław Walczewski "Gryf" 85. W szeregach tej sporej jednostki bojowej, jaką już na przełomie lat 1943 i 1944 stała się siedlecka grupa dywersyjno-bojowa, w dniu 10 czerwca $1944 \mathrm{r}$. było 100 doborowych żołnierzy AK ${ }^{86}$. Nie wiadomo natomiast ilu pochodziło z gminy Skórzec, czyli z Placówki „Kret”. W maju 1943 r. komendant Obszaru I Warszawskiego general Albin Skroczyński „Easzcz” nakazał powołanie na terenie Podokręgu Wschód trzech oddzialów partyzanckich, $\mathrm{z}$ tego jeden $\mathrm{w}$ obwodzie siedleckim. Oddziałem tym dowodził początkowo major Jan Sasin „Kopka”, a potem porucznik Henryk Jackowski „Zemsta”, a ich zastępcami byli podporucznik Jan Tajchert „Kolec” i podporucznik Wacław Dornagała-Polkowski „Piątek”. We wrześniu 1943 r. oddzial ten mial 43 żołnierzy, którzy „rekrutowali się z plutonów z rejonu Skórca”, a więc z plutonu porucznika Domagały „Piątka”. We wrześniu $1943 \mathrm{r}$. oddział ten był wyposażony w 2 ciężkie karabiny maszynowe, 6 ręcznych karabinów maszynowych, 28 ręcznych karabinów i 9 pistoletów.

83 H. Piskunowicz, op. cit., s. 15. Nazwisko tego oficera nie jest znane.

84 Ibidem, passim. Nazwiska wymienionego tu „Komandora” nie udało się ustalić.

85 O sprawach dotyczących siedleckiej jednostki sabotażowo-dywersyjnej szerzej i kompetentnie Henryk Piskunowicz (op. cit., s. 15 i n.). Autorowi niniejszego artykułu chodziło natomiast o wyeksponowanie roli, jaką w walce bieżącej odgrywali akowcy z gminy Skórzec, czyli z Placówki „Kret”.

86 H. Piskunowicz, op. cit., s. 15. 
Nie miał jednak charakteru leśnego. Partyzanci należący do tego oddziału mieszkali we własnych domach i byli mobilizowani doraźnie do konkretnych zadań bojowych ${ }^{87}$.

Na podstawie dostępnych informacji udało się ustalić, że akowcy Placówki „Kret” byli aktywnymi uczestnikami walki bieżącej. Istotną rolę w przebiegu tej walki odgrywały rekwizycje artykułów żywnościowych gromadzonych na żądanie władz okupacyjnych w terenowych magazynach. Takie akcje były przeprowadzane między innymi w Nowakach, Żebraku, Gołąbku, Kotach koło Wiśniewa i w Mościbrodach. Uzyskane w ten sposób artykuły żywnościowe były potem przekazywane potajemnie oddziałom partyzanckiego obozowiska „Jata” w ostępach leśnych na południe od Domanic ${ }^{88}$. Akowcy z Placówki „Kret” nie podejmowali wszakże akcji rekwizycyjnych w tak zwanych Liegenschaftach, czyli majątkach ziemskich przekazanych niemieckim powiernikom po usunięciu z nich polskich właścicieli, ponieważ takich majątków w rejonie Skórca nie było.

Wiadomo natomiast, że członkowie AK z Placówki „Kret” byli uczestnikami ogólnokrajowych akcji dywersyjnych mających na celu niszczenie gminnej dokumentacji dotyczącej tak zwanego kontyngentu, czyli obowiązkowej dostawy produktów rolnych, a także wykazów osób podlegających wysyłce na przymusowe roboty w Rzeszy. Takie akcje, podejmowane na polecenie Kierownictwa Walki Cywilnej i Kierownictwa Walki Podziemnej, były przeprowadzane zwłaszcza wiosną i latem 1943 r. Przez akowców z Placówki „Kret” były one podejmowane w urzędach gminnych Skórca i Żeliszewa $^{89}$. Nie wykluczone, że byli oni także uczestnikami takich akcji w urzędach gminnych Niwisk, Wiśniewa, Domanic i Wodyń. Istnieje natomiast stuprocentowa pewność, że brali udział w zbrojnych napadach na niemieckie pociągi towarowe na zachodnich przedpolach Siedlec, konkretnie na odcinku między przystankami Broszków -- Sabinka. Takie akcje były dokonywane w porozumieniu z polskimi kolejarzami, co umożliwiało przejęcie przewożonych ladunków ${ }^{90}$. Do zestawu niebezpiecznych wyczynów, jakich zdołali

87 Ibidem, s. 16.

88 Podlasie $w$ walce..., s. 2.

89 H. Piskunowicz, op. cit., s. 40.

90 Ibidem, s. 39. Takim akcjom towarzyszyło na ogół powodzenie. Można było niekiedy kupić zupełnie nową część niemieckiego umundurowania. Taki udany zakup uczynili rodzice autora niniejszego artykułu latem 1943 r., gdy nabyli duży płaszcz wojskowy, a po zakończeniu okupacji zostało z niego uszyte moje ubranie. Potwierdzenie tego faktu znajduje się na zachowanym zdjęciu mojej legitymacji szkolnej z 1945 r. 
kilkakrotnie dokonać, należało również to: ścięli sł upy telegraficzne w rejonie Skórca, Wodyń, Żeliszewa, Kotunia i Gręzowa ${ }^{91}$.

$\mathrm{W}$ tej walce, jaką Armia Krajowa toczyła z niemieckimi siłami zbrojnymi ważną rolę odgrywała także łączność. Chodzi tu nie tylko o lokalny system przekazywania służbowych rozkazów, poleceń i raportów, ale także o bezpośrednią przesyłkę ważnych informacji z terenów obwodu siedleckiego do sztabu generała Władysława Andersa we Włoszech i do polskiego ośrodka łączności radiowej Sanmore w Wielkiej Brytanii. Takie informacje były przekazywane za pośrednictwem ośmiu ruchomych radiostacji, które komenda siedleckiego obwodu AK otrzymała w ramach zrzutów lotniczych. Te radiostacje pracowały w różnych miejscowościach powiatu siedleckiego ${ }^{92}$. Jedną z tych miejscowości była gminna wieś Skórzec. Pracująca tu radiostacja była montowana doraźnie na wieży parafialnego kościoła ${ }^{93}$. Działo się to za zgodą przeora klasztoru Ojców Marianów księdza Jana Seferyńskiego, albo proboszcza księdza Daszuty.

W działaniach podejmowanych na rzecz rozbudowy sil Placówki „Kret” czołową rolę odgrywał podporucznik Wacław Domagała-Polkowski „Piątek". W okresie początkowym koncentrowal on swoją uwagę na kompletowaniu stanu osobowego pododdziału, którym dysponowal, a potem był wybitnym uczestnikiem bieżącej walki zbrojnej jako komendant sił Placówki "Kret” i wspomnianego już oddziału partyzanckiego. Nie ma dowodów na to, że przyczynił się do likwidacji lokalnego konfidenta Gestapo, czyli Antoniego Kalecińskiego ze Skórca, ale wiadomo że zamachu na szefa konfidentów Zampfa w gmachu siedleckiego starostwa dokonal czteroosobowy patrol wydzielony $\mathrm{z}$ partyzanckiego oddziału podporucznika Wacława Domagały. Dwaj uczestnicy tej niezwykle ryzykownej akcji pochodzili z Dabrówki Stanów. Byli to Karol Bareja „Bechacz” i Marian Dąbrowski „Żwirek” 94. Według innych informacji Dąbrowski mógł używać również pseudonimu „Mundzio” 95.

\footnotetext{
91 Ibidem, passim.

92 H. Piskunowicz, op. cit., s. 19.

93 Z biogramów Szymona Barabasza „Smiały”, Wacława Czeluścinskiego „Lis” i Edwarda Karczmarka „Cygan”, w: Podlasie w walce..., s. 3, 5 i 9. Nazwisko osoby, kŁóra nadawała informacje za pośrednictwem radiostacji instalowanej w Skórcu nie jest znane.

94 H. Piskunowicz, op. cit., s. 44.

95 Ustna relacja złożona 29 stycznia 2005 r. przeı Barbarę Jastrzębską, która była siostrą Mariana.
} 
Najważniejszym əbrojnym przedsięwzięciem, w którym uczestniczyło wielu akowców gminy Skórzec (Placówka „Kret”), był jednak zamach na niemiecki oficerski urlopowy pociąg pośpieszny (Urlaubsoffiezierzug), dokonany w rejonie wsi Borki Kosy 29 lutego 1944 r. 'Ten zamach został przygotowany pod ogólnym nadzorem komendanta siedleckiego obwodu AK majora Mariana Zawarczyńskiego „Ziemowita”, który dysponował wynikami rozpoznania przeprowadzonego przez porucznika Adama Kompowskiego .Adama”, w porozumieniu z komendą Podokręgu „Białowieża”. Uczestnikami tego zamachu było około 110 żołnierzy należących do partyzanckiego oddziału podporucznika Wacława Domagały oraz wydzielonych przez placówki AK gmin Kotuń, Niwiski i Skórzec. Ogólne dowództwo sprawowal major Jerzy Sasin „Kopka”. Ta akcja była określona kryptonimem „P-1.05”, a chodziło o czas przejazdu wspomnianego pociągu w rozpoznanym rejonie. Zamach ten zakończył się jednak tylko częściowym powodzeniem, ponieważ nie nastąpił wybuch jednej $\mathrm{z}$ trzech min podłożonych pod tory kolejowe. Według komunikatu niemieckiego zginęło tam 14 pasażerów, a kilkudziesięciu odniosło rany. Oddział polski utracił dwóch swoich żołnierzy. Byli to Marian Burgs pseudonim „Bąk” z Dąbrówki Niwki i Marian Prokurat pseudonim „Sarna” z Gołąbka. Obaj spoczywają na parafialnym cmentarzu w Skórcu. Z polskich materiałów wywiadowczych wynikało, natomiast że zginęło około 100 Niemców ${ }^{96}$. Informacje strony polskiej miały jednak zawyżony charakter.

Na system okupacyjnego terroru Armia Krajowa odpowiadała zbrojnymi działaniami obronnymi i akcjami odwetowymi. Wiosną 1943 r. został więc sporządzony wykaz tych funkcjonariuszy Gestapo, policji, SS i cywilnych pracowników niemieckiej administracji, którzy mieli być zlikwidowani. Na czele tego wykazu znaleźli się tacy osobnicy, jak komisarz policji granicznej SS Julius Dube i komisaryczny burmistrz Siedlec Albert Fabisch, odpowiedzialny osobiście za likwidacje siedleckiego getta. Likwidacja wymienionych zakończyła się powodzeniem. W dniu 15 grudnia 1943 r., po kilku nieudanych zamachach, Dube został zastrzelony po wyjściu a zakładu fryzjerskiego przez Zygmunta Koczkodaja pseudonim „Zygmunt” i Mariana Bulika pseudonim Żbik ${ }^{97}$. Fabisch został zabity natomiast dopiero 4 lipca 1944 r. Nie dokonał tego jednak członek AK lecz Narodowych Sił Zbrojnych (NSZ). W odpowiedzi na to władze niemieckie przeprowadziły wielką akcję

96 O tym wydarzeniu szerzej Jerzy Pawkak ( $\Lambda$ kcja kryptonim „P-1.05”, w: Armia Karajowa na środkowej i poludniowej Lubelszczyxnie i Podla.siu..., s. 465-471).

97 H. Piskunowicz, op. cit., s. 45. 
odwetową, a jej wydarzenia rozgrywały się na dużym placu targowym przy ulicy Świętojanskiej. Podczas tej akcji doszło do zabicia 37 osób. W gronie zastrzelonych znalazł się między innymi mieszkaniec wsi Dąbrówki Stany Andrzej Dyduch. Był to człowiek wysiedlony z Gilowic koło Żywca. Ujęto ponadto wiele osób na przymusowe roboty w Niemczech ${ }^{98}$.

Pod koniec drugiej dekady lipca 1944 r. we wsi Dąbrówka Stany rozlokowała się na kwaterach jakaś kompania frontowych wojsk niemieckich. $\mathrm{Na}$ furtce przed domem Wrzosków została wówczas umieszczona tabliczka przymocowana do krótkiej tyczki z napisem "Weber", co miało oznaczać, że w pokoju zamieszkiwanym poprzednio przez nauczyciela porucznika AK Krupę ulokuje się niemiecki oficer o takim nazwisku. W rzeczywistości zamieszkał u nas jednak leutnant Raake i jego ordynans Jakub Schneck. Podczas ich pobytu w naszym domu pojawił się również niespodziewanie porucznik Krupa. Był nawet taki moment, że zetknęli się obaj oficerowie: polski porucznik Krupa w cywilnym ubraniu i niemiecki leutnant Raake. Mierzyli się przez chwilę wzrokiem, ale rozstali się w milczeniu. Polski oficer miał do wykonania sobie tylko znane zadanie i potrzebował noclegu, ale musiał go szukać w innym domu. Pobyt tej niemieckiej kompanii w naszej wsi trwał do 26 lipca. Wymaszerowali $\mathrm{w}$ godzinach przedpołudniowych $\mathrm{w}$ kierunku Siedlec, ale na odcinku szosy między wsiami Skórzec i Dąbrówka Ług zostali ostrzelani z łanów żyta przez oddział partyzancki Henryka Jackowskiego, pseudonim „Zemsta”. Został wówczas zabity jeden $\mathrm{z}$ dwóch jadących konno oficerów niemieckich. Mógł to być ów Weber, ponieważ niebawem pod naszym domem pojawił się ponownie leutnant Raake wraz z grupą żołnierzy. Był bardzo zaszokowany. Może przypuszczał, że atak skierowany przeciw jego kompanii został przygotowany w naszej wsi.

W Dąbrówce Stanach utrzymywał się jednak jeszcze zupełny spokój. Do zbrojnego wystąpienia stanowiącego lokalny fragment słynnej akcji „Burza” doszło dopiero w dniu następnym, gdy na rozkaz podporucznika Domagały żołnierze Placówki „Kret” wydobyli ze schowków swoją broń i, po całodziennych przygotowaniach, udali się do tego samego lasu, w którym znajdowały

98 Autor niniejszego artykułu był naocznym świadkiem tych odwetowych wydarzeí. Doszło wówczas do otoczenia na placu wielkiej liczby osób, ponieważ był to dzień targowy. Selekcja osób odbywała się w luce kordonu wojskowego. Moja Mama została przepuszczona przez selekcjonera, a ja byłem odgarnięty lewą ręką tego osobnika w tłum otoczonych osób. Jeden z żołnierzy ustawionych kordonem skinął jednak palcem, abym się przemknął na zewnątrz pod trzymanym przez niego poprzecznie karabinem ręcznym, co skwapliwie uczyniłem. Miałem wówczas dokładnie 14 lat, a w Siedlcach znalazłem się wówczas z tego powodu, że zbliżał się front i przyjechaliśmy, aby zrobić sobie zdjęcie w fotograficznym zakładzie Kaniewskiego przy ulicy Piłsudskiego (wówczas Hitlera). 
się umocnione pozyc.je oddziału polskiej kawalerii we wrześniu 1939 r. Wyruszyli tam o zmierzchu, a wrócili do domów około północy. Nie sposób ustalić kto zadecydowal o tym powrocie.

Niebawem nastąpił tragiczny epilog tych burzliwych wydarzeń. Na obszarach opuszczonych przez wojska niemieckie zapanowal terror NKWD. Rozpoczęło się intensywne tropienie członków konspiracyjnych organizacji. Zapełniły się znowu cele siedleckiego więzienia i obozu założonego w Krześlinie na północ od Siedlec. Aresztowani byli tam przetrzymywani w zwyczajnych dołach. Udręczonych w ten sposób akowców poddawano uciążliwym dochodzeniom. Zapadały tylko ciężkie wyroki; śmierci, albo o pobycie w sowieckich lagrach przez 10 lub 15 lat. 'Te drakońskie wyroki wydawał sąd polowy wojsk I Frontu Białoruskiego.

Dochodziło również do bratnich skrytobójczych mordów. W takich właśnie okolicznościach 7 października 1944 r. zginęli czterej wybitni akowcy ze Skórca, a mianowicie podporucznik lekarz weterynarii Ludwik Ossowski „Doktor", jego brat kapral podchorąży Henryk Ossowski „Osa”, Czesław Skóra „Czesiek” i Stanisław Wiechetek. Został wtedy zamordowany także podporucznik Józef Izdebski z Wodyín, ranny uciekinier z krześlińskiego obozu. Morderstwo nastąpiło na szosie garwolińskiej w rejonie Woli Wodyńskiej ${ }^{99}$. W tym czasie był zamordowany również porucznik Jan Kazimierz Krupa, który był już wówczas nauczycielem szkoły powszechnej w Wilczyskach pod Żelechowem. Z ustaleń nie opartych na informacjach $w$ pełni udokumentowanych wynika, że został zakopany w jakimś lesie, w tak zwanym wilczym dole ${ }^{100}$. Porucznik Stanisław Dąbrowski ujawnił się natomiast i wstąpił do ludowego Wojska Polskiego. Uczestniczył w działaniach wojennych, a potem wraz z żoną, która wróciła z zesłania $\mathrm{w}$ głąb ZSRR, żył jako osadnik rolny na ziemi lubuskiej. Starszy wachınistrz Kazimierz Zamyłko pseudonim „Koń” wyjechał wraz z rodziną z Dąbrówki Stanów na Pomorze Zachodnie. Osiedlił się w Miastku (powiat koszaliński) przy ulicy Kaszubskiej 14. W Miastku przez dłuższy czas przebywał również Marian Dąbrowski pseudonim „Żwirek”, a potem osiadł w Radomiu i uniknął aresztowania.

Tragiczny los nie ominął natomiast podporucznika Wacława Domagały, który nie ujawnił się. Był uporczywie poszukiwany przez funkcjonariuszy powiatowego Urzędu Bezpieczeństwa Publicznego, ale został ujęty prawdo-

99 H. Piskunowicz, op. cit., s. 56.

100 Informacja przekazana autorowi artykułu przez oficera AK Romana Germatę około $1980 \mathrm{r}$. 
podobnie dopiero w 1946 r. Podczas długotrwałych przesłuchań był torturowany i okrutnie bity. Potem został uwięziony i w wyniku tych przejść utracił wzrok. Nie ujawnił się również Karol Bareja pseudonim „Bachacz” i nie pozbył się ani broni, ani sporego zapasu amunicji oraz granatów. Ukrywał się w rodzinnych stronach do trzeciej dekady maja $1946 \mathrm{r}$. W tym czasie utracił już nadzieję na jakieś rychłe zmiany polityczne i tak się zachowywał, jakby szukał śmierci. W dniu 26 maja pojawił się na wiejskiej zabawie tanecznej w Dąbrówce Stanach, ale został zadenuncjowany przez jednego z mieszkaíców, który był tajnym współpracownikiem powiatowych władz bezpieczeństwa. Nastąpiło więc otoczenie sali tanecznej przez kilkunastoosobową grupę funkcjonariuszy bezpieczeństwa, a Bareja ukrył się na strychu sali tanecznej, usytuowanej obok wozowni w remizie ochotniczej straży pożarnej. Po wylegitymowaniu osób obecnych na sali nastąpiły skrupulatne poszukiwania i doszło do nierównej walki, która toczyła się do wyczerpania amunicji przez osaczonego Bareję. Podczas tej walki, trwającej parę godzin, zginął jeden $\mathrm{z}$ funkcjonariuszy bezpieczeństwa, a Karol Bareja „Bechacz” odebral sobie życie odbezpieczonym granatem ${ }^{101}$. W 1949 r. został aresztowany kapral Antoni Sitarz „Zagoda” z Dąbrówki Stanów i przẹbywał w więzieniu do 1952 r. Nie został natomiast schwytany kapral Józef Jastrzębski z Dąbrówki Stanów, chociaż był tropiony przez 7 lat. Aresztowania obawiał się także Lucjan Obłoza z Dąbrówki Niwki i w związku z tym po wojnie zamieszkał w Warszawie. Podobno był osobistym kierowcą ministra jakiegoś resortu.

The underground system of education and military conspiracy in the south-western region of South Podlasie in the years 1939-1944

\section{Abstract}

The present paper provides an analysis of the available publications on the subject; it also draws information from the data obtained from the participants of the events described here, as well as the memories of the present author.

First, the article discusses the events which in 1939 led to the German occupation in the district of Siedlce, concentrating on the situation in the area of Skórzec located in the south-western part of the region. It describes the military activities that took place in the west borderland of the region in September 1939; then it concentrates on the system of German occupation as well as the military and police

101 M. Roman, Smierć Karola Barei „Bechacza”, „Jednodniówka Siedlce - Warszawa, 26 maja 1999", s. 1-5. 
forces that the German authorities had at their disposal in the region of Siedlce. The paper discusses also some issues connected with underground education in Skórzec, which was organized by Feliksa Wąsikowa, who had been a lower secondary school ("Gimnazjum") teacher in Ostrów Wielkopolski before the Second World War. Another person actively involved in underground education in the area was Jan Seferyniski, prior of the local Marian convent.

However, the main focus of the paper is issues connected with the resistance movement, in particular, armed fighting. On the basis of the collected reports and personal memories, the activities of the Polish underground army "Armia Krajowa" in the area of Skorzec have been described (the unit in Żeliszew was called Kret "Mole", known also as "Żelbeton", and later "Ogródek". That section of the article includes names of $\mathrm{AK}$ soldiers as well as their pseudonyms, the most important of them being Second Lieutenant Waclaw Domagała ("Piątek"), a reserve officer; Lieutenant Jan Kazimierz Krupa, a reserve officer; Second Lieutenant Ludwik Ossowski ("Doktor"); his brother corporal Henryk Ossowski "Osa", and Karol Bareja "Bechacz". The article ends with the analysis of the events that took place in Skórzec in the last decade of July 1944, after the German army had left the area.

\section{Из истории тайного обучения и военной конспирации на юго-западной территории Южного Подляшья в 1939-1944 гг. \\ Резюме}

Статья основана на фактах, имеюцихся в доступных разработках, а также на информации, полученной от участников тогдашних событий, и на собственных воспоминаниях автора.

Начальные фрагменты этой статьи касаются тех событий, которые осенью 1939 г. привели к установлению немецкой оккупапионной системы на территории седлецкого района, обрашая особое внимание на то, что происходило в гмине Скужец, то есть на юго-западной территории этого района. И так, сначала были представлены события, связанные с ходом сентябрьских сражений на запацном пограничье гмины, а затем вопросы, касаююциеся немецкой оккупационной системы, а также вооруженных сил и полиции, имеюгцихя в седлецком районе в распоряжении немецких оккупационных властей. Был также пролит свет на вопросы, связанные с тайным обучением в гмине Скужец. В качестве организатора такого обучения оставила о себе память Феликса Вонсиковая, которая до начала войны была учителем гимназии в Острове Велькопольским. Значительную роль в этой ответственной деятельности сыграл также настоятель мужского монастыря Отцов Марианов ксендз Ян Сеферыньский.

Наиболее обширно были учтены вопросы, связанные с движением сопротивления, особенно те, касаюшиеся вооруженной борьбы. На основе полученньг сообщений, а также собственньх воспоминаний были представлены факты, касаюшиеся сил Армии Краевой в гмине Скужец (Пост «Крот» 
в Центре Желипев, условное название «Железобетон» (позже «Огородчик»). В этих фрагментах статьи нашлись именные списки солдат $\mathrm{AK}$, а также частично их псевдонимы. Ведушую роль в этих вооруженных действиях сыграл подпоручник запаса Вацлав ЦІомагала, псевдоним «Пятница». Кроме того, больпую активность проявляли поручник запаса Ян Казимир Крупа, подпоручник запаса Людовик Оссовский «Доктор», его брат капрал подхоружи Генрых Оссовский «Оса» и Кароль Барея «Бехач». Заключительные фрагменты статьи включают в себя описание тех событий, которые произошли в гмине Скужец уже после ухода немецких войск в последнюю декаду июля 1944 r. 